\title{
Switzerland: 2004 Article IV Consultation-Staff Report; Public Information Notice on the Executive Board Discussion; and Statement by the Executive Director for Switzerland
}

Under Article IV of the IMF's Articles of Agreement, the IMF holds bilateral discussions with members, usually every year. In the context of the 2004 Article IV consultation with Switzerland, the following documents have been released and are included in this package:

- the staff report for the 2004 Article IV consultation, prepared by a staff team of the IMF, following discussions that ended on March 8, 2004, with the officials of Switzerland on economic developments and policies. Based on information available at the time of these discussions, the staff report was completed on May 12, 2004. The views expressed in the staff report are those of the staff team and do not necessarily reflect the views of the Executive Board of the IMF.

- a Public Information Notice (PIN) summarizing the views of the Executive Board as expressed during its June 2, 2004 discussion of the staff report that concluded the Article IV consultation.

- a statement by the Executive Director for Switzerland.

The policy of publication of staff reports and other documents allows for the deletion of market-sensitive information.

To assist the IMF in evaluating the publication policy, reader comments are invited and may be sent by e-mail to publicationpolicy@imforg.

Copies of this report are available to the public from

International Monetary Fund • Publication Services

$70019^{\text {th }}$ Street, N.W. • Washington, D.C. 20431

Telephone: (202) 623-7430 - Telefax: (202) 623-7201

E-mail: publications@imforg • Internet: http://www.imf.org

Price: $\$ 15.00$ a copy

\section{International Monetary Fund \\ Washington, D.C.}


INTERNATIONAL MONETARY FUND

SWITZERLAND

\section{Staff Report for the 2004 Article IV Consultation}

Prepared by the Staff Representatives for the

2004 Consultation with Switzerland

Approved by Alessandro Leipold and G. Russell Kincaid

May 12, 2004

The 2004 Article IV consultation discussions were held in Zürich and Bern during February 27-March 8, 2004. The mission comprised Messrs. Haas (Head), Gagales, and Braumann and Ms. Giuliano (all EUR). Messrs. Zurbrügg, Executive Director for Switzerland, and Moser, Senior Advisor, attended the meetings. The mission met with Federal Councillor Merz, Minister of Finance; President Roth, Chairman of the Governing Board of the Swiss National Bank (SNB); Mr. Syz, Director of the Federal Economic Secretariat (SECO); senior officials of the federal administration and the SNB; and representatives from the private sector and NGOs. The authorities released the mission's concluding statement and have agreed to the publication of the staff report.

Switzerland has accepted the obligations of Article VIII, Sections 2, 3, and 4 (Appendix I) and maintains an exchange system that is free of restrictions on payments and transfers for current international transactions, except those imposed solely for security reasons. Switzerland subscribes to the Fund's Special Data Dissemination Standard (Appendix II). The last Article IV consultation was concluded on May 23, 2003 (IMF Country Report No. 03/148). 
Contents

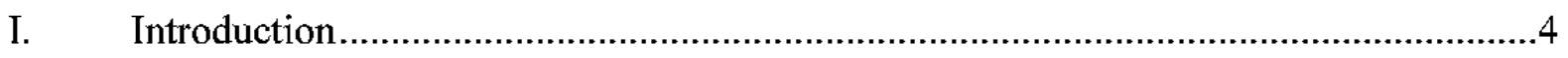

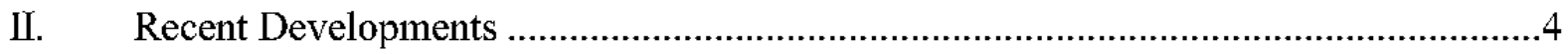

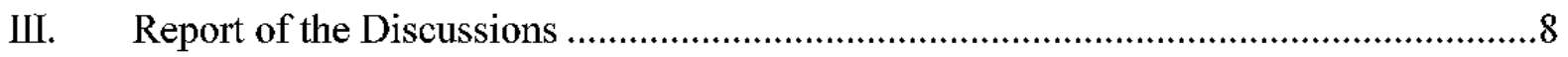

A. Near-Term Outlook: The Recovery is Gathering Steam.........................................

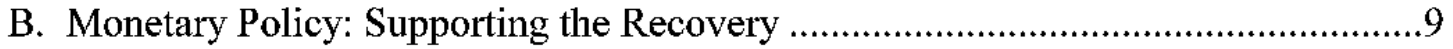

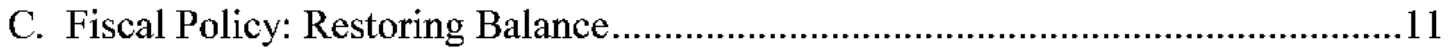

D. Financial Sector: Coming Out of the Woods .....................................................

E. Structural Issues: Invigorating Growth......................................................... 16

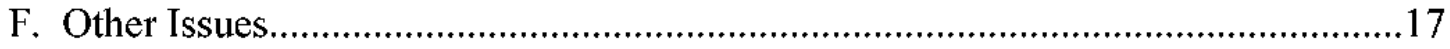

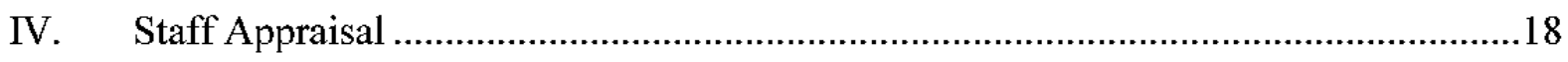

\section{Boxes}

1. A Century of Real Appreciation for the Swiss Franc .............................................21

Tables

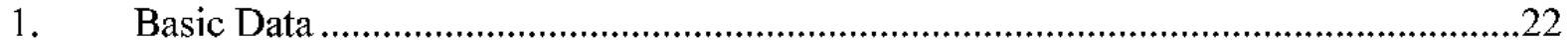

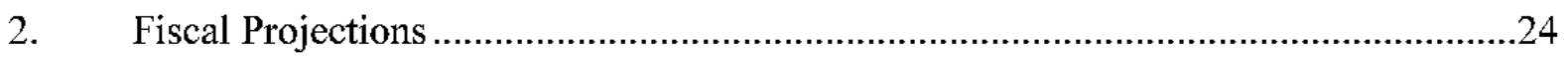

3. Indicators of External and Financial Vulnerability ..............................................25

Figures

1. Main Economic Indicators in International Perspective, 2001-2003 ........................26

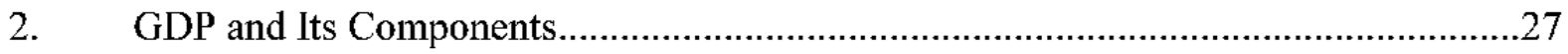

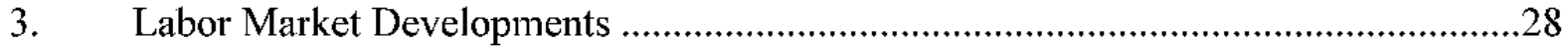

4. Inflation Has Been and Is Expected to Remain Low ..........................................29

5. Monetary Conditions Have Eased........................................................................... 30

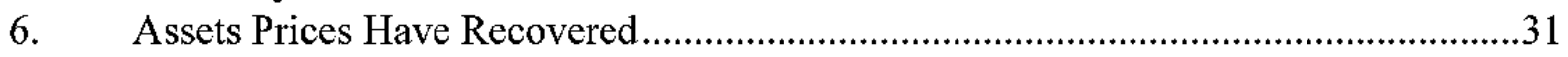

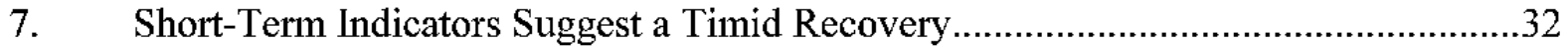

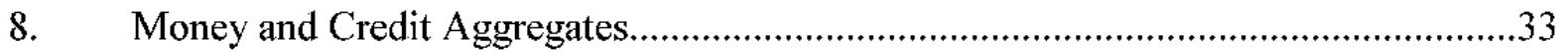

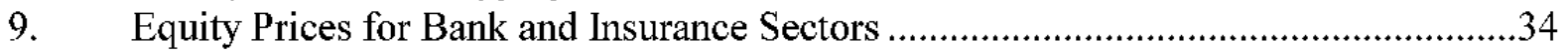

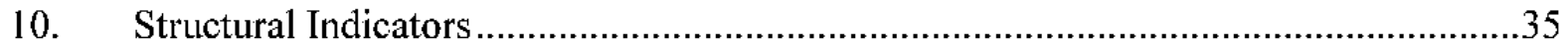

Appendices

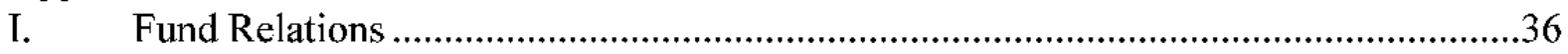

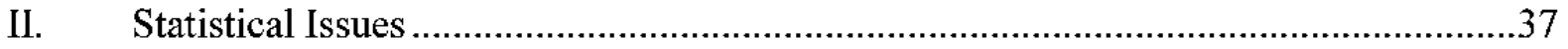

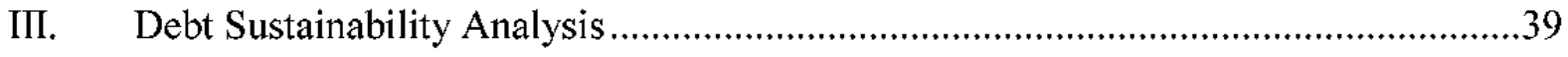




\section{Main Websites for Swiss Data}

Data in this Staff Report reflect information received by April 30, 2004. In most cases, more recent data can be obtained directly from the following internet sources:

Swiss Federal Statistical Office http://www.statistik.admin,ch

Swiss National Bank htop:/www snb.ch

State Secretariat for Economic Affairs (SECO) hip:/irww seco-admin.ch

Federal Ministry of Finance. lntp:/ww efdadmin, ch

Federal Customs $\Lambda$ dministration hup/ www zolladmin.ch

Institute for Business Cycle Research at the Federal Institute of 'lechnology (KOF). hintp:/ www.kofethr.ch

Information and documentation on Swiss economic statistics can be found at the Special

Data Dissemination Standard website of the IMF htp:/www.int.org/extermal/country/CHE/index,htm

\section{Main Acronyms used in this Report}

$\begin{array}{ll}\text { AHV } & \text { Old Age and Survivors Insurance } \\ \text { ALV } & \text { Unemployment Insurance } \\ \text { BfS } & \text { Federal Statistical Office } \\ \text { BPV } & \text { Federal Office of Private Insurance } \\ \text { EBK } & \text { Tederal Banking Commission } \\ \text { ETH } & \text { Federal Institute of Technology } \\ \text { IV } & \text { Disability Insurance } \\ \text { KOF } & \text { Institute for Business Cycle Research at the Federal Institute of Technology } \\ \text { Seco } & \text { State Secretariat for Economic Affairs } \\ \text { SMI } & \text { Swiss Market Index } \\ \text { SNB } & \text { Swiss National Bank } \\ \text { SUVA } & \text { Swiss Accidence Insurance }\end{array}$




\section{INTRODUCTION}

1. Switzerland's economic performance has been, at best, mixed over the past several years. On the positive side, prudent monetary policy has delivered low inflation and flexible labor markets have kept unemployment low by international standards (Figure 1). Moreover, a business-friendly environment in conjunction with a skilled labor force have supported a high per capita income and standard of living. But, with the exception of a brief interlude in 1998-2000, economic activity has largely been stagnant since the early $1990 \mathrm{~s}$, leading to a repeated flirting with recession and pressure on the public finances. This has sparked an ongoing public debate about the dynamism of the economy and, in response, the government has recently put forward a reform agenda for opening up sheltered sectors and strengthening Switzerland's attractiveness as a business location in an effort to increase trend growth.

2. This strategy is broadly in line with previous IMF advice, although implementation of structural reforms has lagged. At the conclusion of the 2003 Article IV consultation, Executive Directors commended the authorities' sound macroeconomic management and, against the backdrop of weak economic activity, urged them to continue pursuing an accommodative monetary policy while avoiding a pro-cyclical implementation of the fiscal rule. The authorities have continued their supportive policy stance. More generally, Fund advice has centered on the fiscal and monetary frameworks, specially the formulation of the debt-brake and the shift from targeting monetary aggregates to medium-term price stability. Insufficient competition in domestic markets, which has undermined Switzerland's growth potential, has been a theme in all recent consultations. Acceleration of reforms has been urged for some time with a focus on barriers to the internal market, cartels, and sheltered sectors. The authorities supported reforms of this nature but have found it difficult to mobilize wider popular support, the sine qua non in the Swiss federalist structure where government decisions can be challenged with referenda. The authorities have always disseminated widely the conclusions of Fund missions.

\section{ReCENT DeVelopMent'S}

3. The Swiss economy has been hit hard by the global slowdown but recent indicators suggest that activity has started to pick up. After showing some spark in the late $1990 \mathrm{~s}$, the economy came close to a recession twice in the past three years. The main contributing factors were the slump in external demand (due to both lower foreign demand and the sharp appreciation of the Swiss franc through early 2003) and a collapse in domestic investment after the hefty investment spending in the late 1990s (Figure 2). Switzerland has also been hit by a series of shocks affecting three of the country's main sectors: financial services, capital goods manufacturing, and tourism. And private consumption was frail in the wake of financial problems at pension funds and rising unemployment. Despite the pick-up in activity in the second half of 2003 driven by stronger exports (in line with the rebound in 
world demand) and domestic investment (reflecting improved business conditions), real GDP contracted by $1 / 2$ percent in 2003 as a whole, widening the output gap to $2-2 \frac{1}{2}$ percent. $^{1}$

Switzerland: Contributions to Growth Deceleration

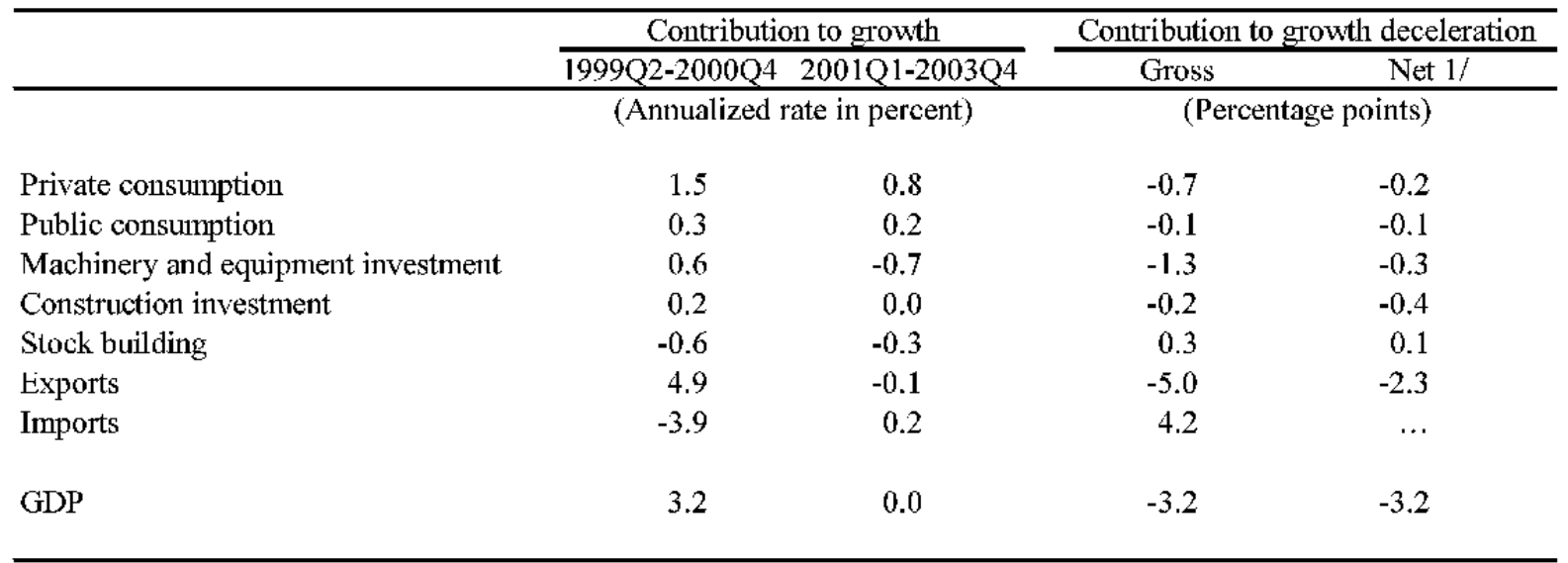

Sources: SECO; and IMF staff calculations.

1 / Net of the import content of private consumption, machinery and equipment investment, stock building, and exports. The import content is estimated, respectively, at 20,75,50 and 55 percent. Import contents of public consumption and construction investment are set to zero.

Labor prodactivity stagnated recently...

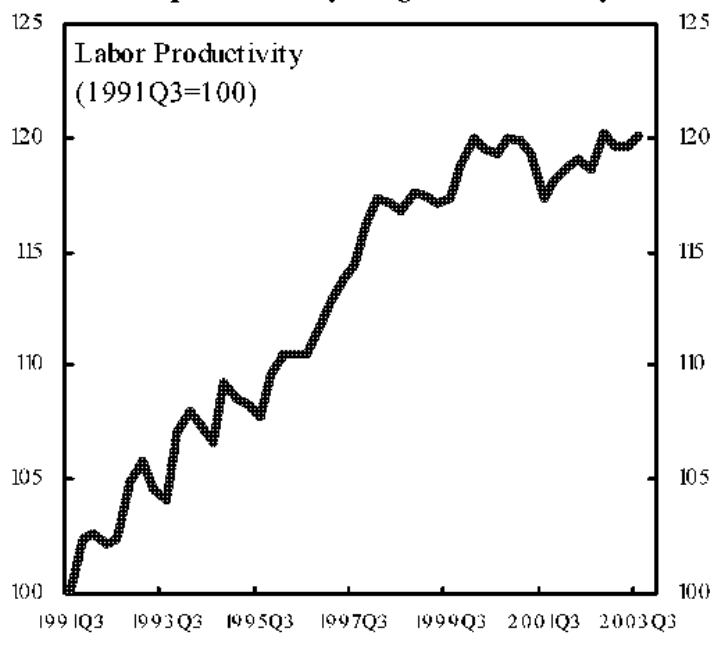

...unlike in other industrial countries.

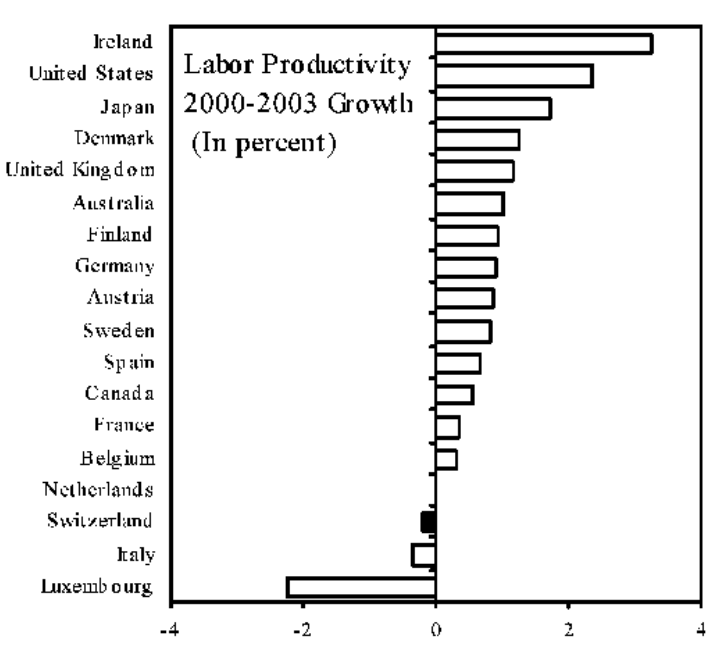

4. The weakness in economic activity has led to a deterioration in labor market conditions. Registered unemployment has risen sharply, but at 4 percent is low by international standards, partly due to the rise in part-time employment, withdrawals from the labor force, and increased participation in active labor market programs (Figure 3). Since

${ }^{1}$ The output gap estimate is subject to considerable uncertainty, not least because the elastic pool of foreign workers makes it difficult to gauge potential labor supply. 
2000 , there has been a moderate contraction in employment and labor productivity has remained flat.

5. Inflation has been very low throughout the current business cycle. After peaking at 1.9 percent in 2000 , inflation receded and, in the past twelve months, has not exceeded $1 / 2$ percent. It benefited from declining import prices, widening economic slack, increasing competition in retailing - where clothing prices dropped cumulatively by 16 percent in the past three years - and wage moderation (Figure 4). Meanwhile, prices in sheltered sectors such as education and public services continued to grow by about 2 percent. With deteriorating labor market conditions, collective wage increases decelerated to 1.4 percent in 2003 and recent wage agreements envisage rises of about 1 percent in 2004.

6. With inflation very low and expected to remain well below 2 percent in the foreseeable future, the SNB has eased monetary conditions considerably. Since 2001, the three-month benchmark interest rate has been cut by 325 basis points ( 50 basis points more than in the euro area) to just $1 / 4$ percent, pushing real short-term interest rates into negative territory (Figure 5). However, real borrowing costs declined less because the yield curve steepened, banks raised interest margins to strengthen their income position, and inflationary expectations receded. Domestic credit has stagnated, despite an almost 10 percent annual expansion in broad money. Equity prices (SMI) have risen by 35 percent since their trough in March 2003, mirroring the turnaround in other financial centers (Figure 6).

\section{The partial reversal of the earlier sharp appreciation of the Swiss franc has} reinforced the monetary stimulus. The Swiss franc appreciated significantly from mid-2001 through early 2003, as geopolitical uncertainties and concerns about the global outlook prompted a flight to safe-haven currencies. Subsequently, the safe-haven effect has dissipated somewhat and the recovery in other financial markets has induced some investors out of Swiss franc assets. As a result, the franc has weakened by 6 percent since early 2003 against the euro.

The nominal effective exchange rate...

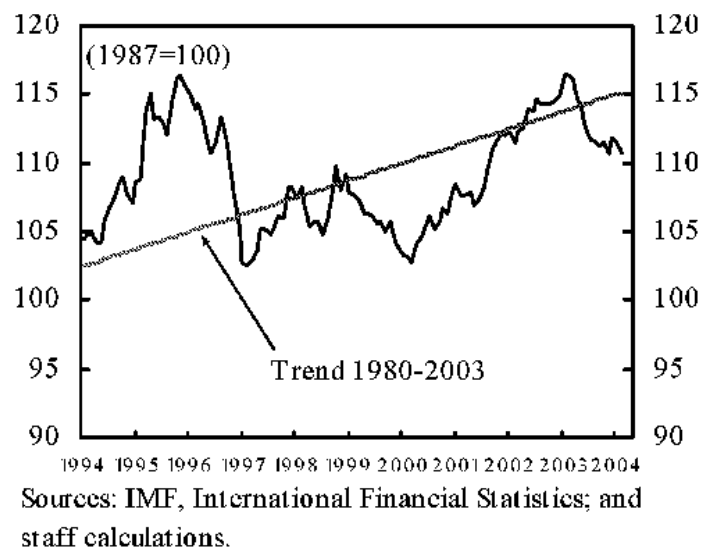

....and the real one have weakened recently.

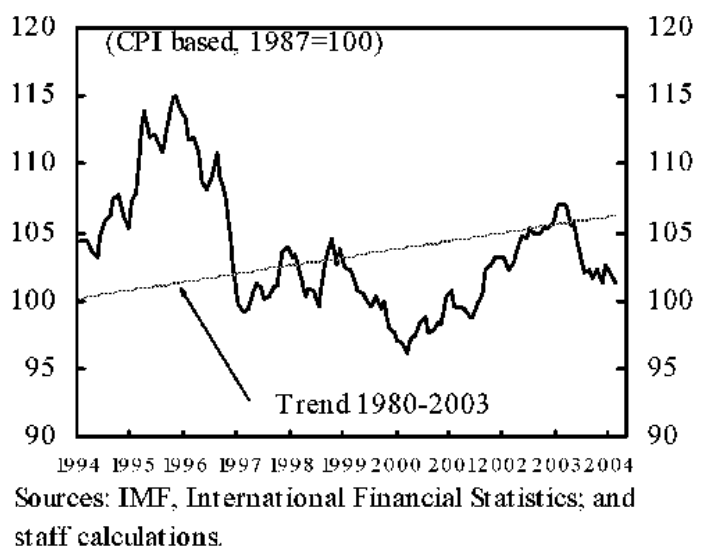




\section{The external current account surplus} remains high. After a dip in 2001 due to lower net investment earnings, the current account surplus rebounded to around 10 percent of GDP. The bulk of the current account surplus appears to be structural (see IMF Country Report 00/43).

9. Fiscal policy has been accommodative. The general government deficit widened to 2 percent of GDP in 2003 and is budgeted to rise to $2 \frac{1}{2}$ percent in 2004 , implying some injection of stimulus. This deterioration, which is evident at all levels of government, reflects, in addition to the play of automatic stabilizers, a decrease in

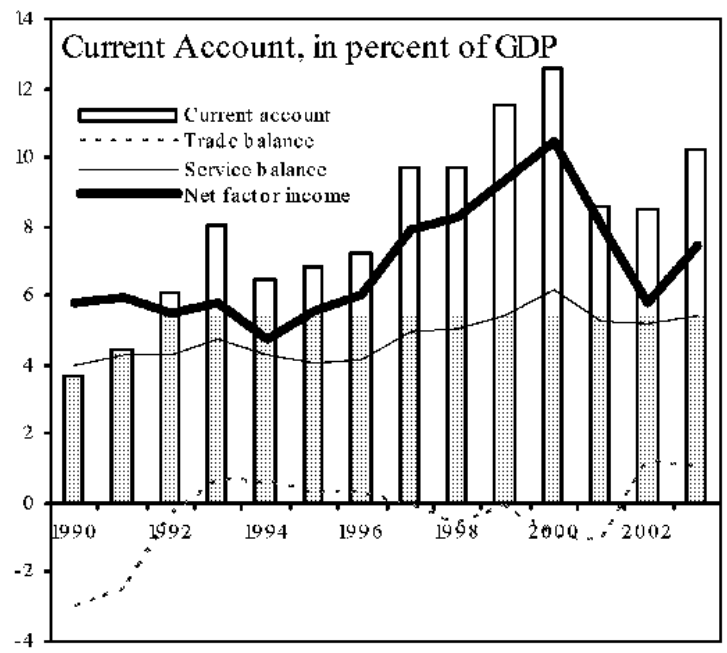
revenue from the financial sector following the burst of the global equity bubble. Public sector debt is estimated to have inched up to 56 percent of GDP at end-2003.

Switzerland: Fiscal Accounts 2000-2004

\begin{tabular}{lrrrrr}
\hline & 2000 & 2001 & 2002 & 2003 & 2004 \\
\hline & \multicolumn{5}{c}{ (In percent of GDP) } \\
General government & 38.3 & 37.3 & 37.1 & 37.3 & 36.9 \\
$\quad$ Revenue & 36.1 & 37.2 & 38.4 & 39.2 & 39.4 \\
Expenditure & 2.2 & 0.0 & -1.2 & -1.9 & -2.5 \\
Balance & & & & & \\
& 12.5 & 11.7 & 12.0 & 11.0 & 11.0 \\
Federal government & 11.2 & 10.1 & 10.0 & 10.1 & 10.2 \\
Revenue & 2.6 & 2.9 & 2.6 & 2.9 & 2.8 \\
$\quad$ Tax revenues & 1.5 & 0.2 & 0.6 & 0.4 & 0.6 \\
$\quad$ Direct federal taxes & 1.0 & 0.8 & 0.7 & 0.6 & 0.7 \\
$\quad$ Withholding tax & 4.0 & 4.0 & 3.9 & 4.0 & 4.0 \\
$\quad$ Stamp duty & 1.3 & 1.5 & 2.0 & 0.9 & 0.8 \\
$\quad$ VAT & 0.1 & 0.1 & 0.9 & 0.0 & 0.0 \\
$\quad$ Non-tax revenues & 11.6 & 12.1 & 12.1 & 11.9 & 12.3 \\
$\quad$ Privatization proceeds & 10.0 & 10.1 & 10.4 & 10.3 & 10.4 \\
$\quad$ Expenditure & 1.3 & 1.8 & 1.4 & 1.3 & 1.3 \\
$\quad$ Current expenditure & 0.9 & -0.4 & -0.1 & -0.9 & -1.3 \\
$\quad$ Capital expenditure & &
\end{tabular}

Sources: Federal Ministry of Finance; and IMF' staff calculations. 


\section{REPORT OF TIIE DISCLSSIONS}

10. This year's consultation took place in a familiar environment with one difference: a lesser scope for demand management policies. In each of the previous two consultations, activity was weak, though projected to gradually pick up, albeit with a non-negligible probability of a deflationary episode. However this time, unlike the past, the room to cut interest rates further has been practically exhausted and the structural fiscal deficit has widened. Against this background, the consultation focused on the conduct of monetary policy in a low inflation, low interest rate environment; the pace and timing of the withdrawal of monetary stimulus; the restoration of fiscal balance and the operation of the fiscal rule; the adjustment of the financial sector to pressures from the economic environment as well as the implementation of FSAP recommendations; and structural policies to boost potential growth.

\section{A. Near-Term Outlook: The Recovery is Gathering Steam}

11. The conjunctural factors that depressed the Swiss economy over the past three years are receding. In the key financial sector the worst appears to be over, corporate balance sheets and profitability are strengthening, the investment climate is improving, and leading economic indicators suggest that the nascent recovery has been gathering steam (Figure 7). The authorities did not see major imbalances that could hold back the recovery, other than some longstanding structural problems in tourism. With exports at almost half of GDP, the recovery would hinge primarily on accelerating foreign demand, especially in the EU (the destination of 55 percent of Swiss exports). At the time of the mission, the authorities, private forecasters and staff all projected real GDP growth to pick up to $1 \frac{1}{2}$-2 percent in 2004 and remain at about 2 percent in 2005 , somewhat above potential growth, with risks evenly balanced.

12. While the prospect remains that of a gradual recovery, recent events have tilted the balance of risks to the downside. The main downside risks are seen to stem from a faltering in the recovery of Switzerland's major trading partners, a further strengthening of the euro that could undermine recovery in the EU, geopolitical risks that could lead to a sharp safe-haven appreciation of the franc, and turmoil in international financial markets that could negatively affect the financial sector. Unlike several other industrial countries, the Swiss real estate market does not present a serious downside risk: abstracting from some localized overheating, property price increases have been modest by international standards and current price levels are 20-30 percent below their peak in 1990 (Figure 6).

13. Deflation risks appear to have ebbed and the prospects of inflation pressures in the near future were seen as slim. A weakening in activity or a strengthening of the franc could still push inflation into negative territory; but the chances of this happening are receding. On the upside, there has been a rapid build up of liquidity but, with the output gap currently at $2-2 \frac{1}{2}$ percent, GDP growth could rise to $2 \frac{1}{2}$ percent for several years before inflation pressures become a concern. 


\section{B. Monetary Policy: Supporting the Recovery}

14. With inflation expected to remain well within the $0-2$ percent price stability range in the next few years and the recovery not yet assured, the SNB signaled its intention to maintain its accommodating monetary policy stance for the time being, while noting a tightening bias. The Monetary Conditions Index (MCI) indicates a considerable monetary stimulus and the policy interest rate is consistent with the Taylor rule.
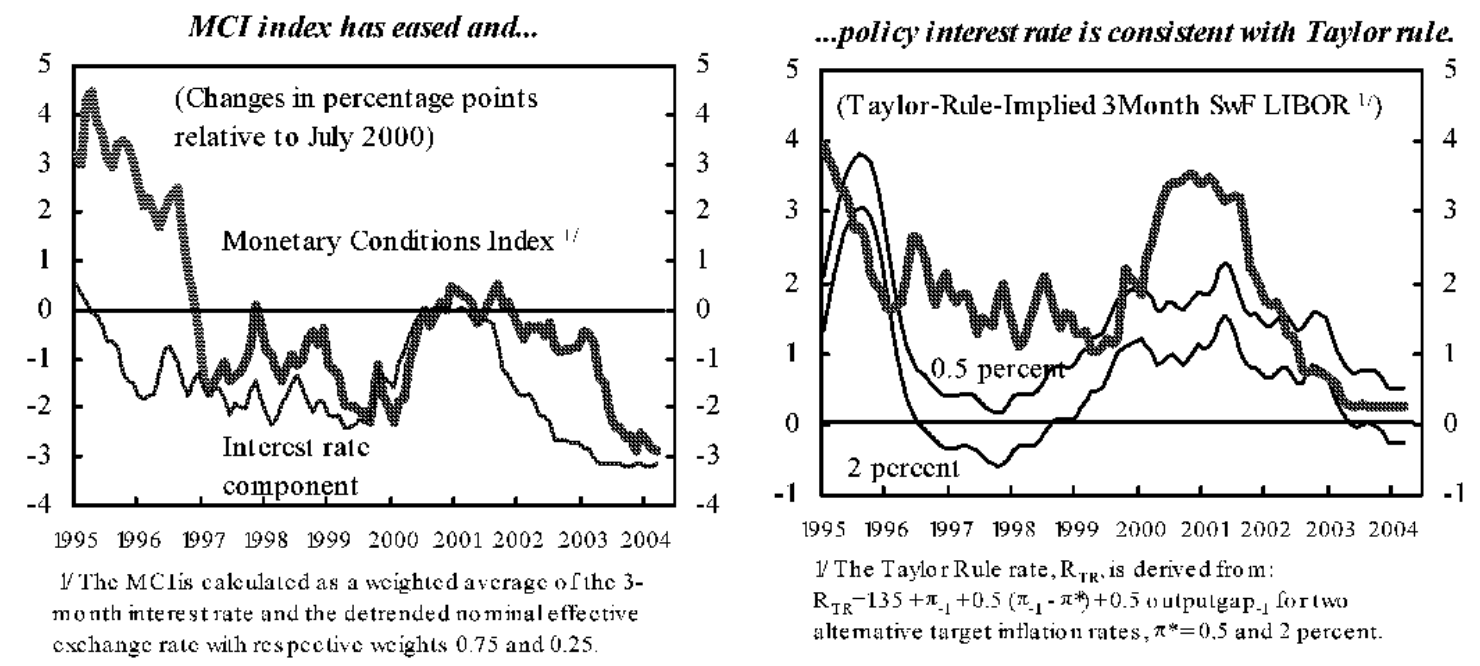

But, as the current very low level of interest rates cannot be maintained indefinitely, the key policy challenge is the timing and pace of the tightening so as to avoid jeopardizing the nascent recovery. The SNB saw little inflation risk from a brief delay in raising interest rates as, even with unchanged interest rates, inflation was forecast to remain below $1 / 2$ percent in 2004 and reach the upper limit of the price stability range only in 2006 as slack in activity was eliminated. Staff argued for maintaining the expansionary stance until convincing evidence of a sustainable and broad-based recovery in domestic demand emerged, and recommended a strategy of gradual interest rate increases to minimize expectation surprises, asset market volatility, and output losses. Subsequent to the mission, the SNB noted that it did not wish to threaten the upswing by raising interest rates too soon, but reaffirmed its intention to tighten policy once signs of recovery are fully confirmed. Markets seem to have taken note of the SNB's tightening bias, expecting a fairly early increase, as suggested by recent rises in Markets expect some tightening in 2004

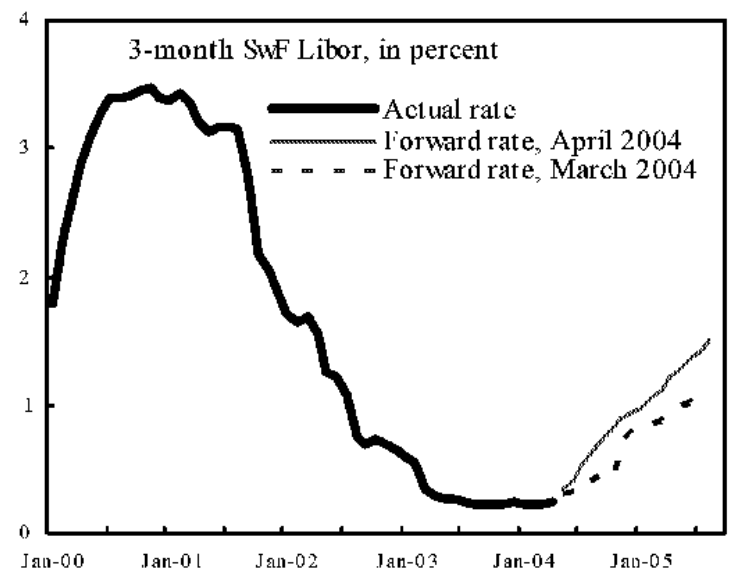
forward rates. 


\section{Staff agreed that the rapid money growth did not present an immediate upside} inflation risk but needed to be monitored closely. Although the short-term relation between money and inflation is rather tenuous due to the instability of money demand, ${ }^{2}$ staff noted that the monetary expansion at the rate of 8 percent in the past year could not be sustained for long without endangering price stability. The SNB argued that this rapid money growth had been largely driven by temporary portfolio shifts following the burst of the equity bubble that were likely to be reversed as financial market conditions improved, and by lower interest rates. ${ }^{3} \mathrm{~A}$ broader money aggregate that included fiduciary accounts, mortgage bonds and bank bonds appears to be more stable and closely correlated to turning points in stock market prices (Figure 8). A second assuaging factor is that the rapid money growth has not yet filtered into credit growth: apart from mortgage lending to households, all other forms of bank lending, and, in particular, lending to enterprises, have been declining. This reflects both lower demand - due to lower investment and enterprises' efforts to strengthen their balance sheets - and a lower supply of credit as banks have been tightening lending practices and introducing risk-based lending interest rates. The SNB did not find strong evidence of credit channel effects or of systematic discrimination against small and medium-sized enterprises.

16. A challenge for monetary policy could come if significant appreciation pressures were to materialize at a time of considerable economic slack and near-zero interest rates. The SNB explained its readiness, in these circumstances, to engage in quantitative easing in the form of unsterilized foreign exchange intervention and purchases of domestic securities (the revised National Bank Law now gives the SNB considerable flexibility in choosing the gamut of financial instruments). Staff agreed that such steps could be effective in countering an unwanted tightening of monetary conditions in the short-term, and noted that lengthening the maturity of the policy interest rate beyond three months could increase the scope for cutting interest rates within the constraints of the zero interest rate floor. The authorities took note of the staff's suggestion to raise the inflation objective to the top half of the $0-2$ percent range of price stability as a means also to avoid having to resort to unconventional monetary policy instruments in future downturns, but did not see the need for change at the present time.

\section{On the other hand, from a longer-term perspective, SNB officials did not} consider the trend real appreciation of the franc as problematic for competitiveness. Notwithstanding problems that the weak dollar has created for some exporters, in real

\footnotetext{
${ }^{2}$ Short- and medium-term inflation dynamics in Switzerland are driven mainly by the slack in economic activity, the exchange rate pass-through, and productivity shocks (see IMF Country Reports $03 / 149$ and $01 / 75$ ).

${ }^{3}$ With lower interest rates, funds held abroad in tax exempt fiduciary accounts were transferred to accounts in Switzerland as, at very low interest rates, the fees on fiduciary accounts outweighed the benefit from avoiding the withholding tax.
} 
effective terms, the franc is below its longer-term trend. This was consistent with the staff assessment that the exchange rate is below its fundamental equilibrium rate (Box 1).

\section{Fiscal Policy: Restoring Balance}

18. The overall fiscal position is relatively sound, current strains and longer-term challenges notwithstanding. At 21/2 percent of GDP, the general government deficit for 2004 is moderate by international standards; and, under current policies, it is projected to decline gradually toward 1 percent of GDP, which is consistent with a constant debt/GDP ratio (Table 2). Over the longer term, Switzerland is better prepared to deal with the fiscal challenges of population aging than most other European countries because it relies heavily on a fully-funded second pillar, public debt is a moderate 56 percent of GDP, and public consensus has been building for the need to address these longer-term issues. On the latter, the authorities observed that debt could rise by another three percentage points of GDP due to contingent liabilities related to the capitalization of public, or

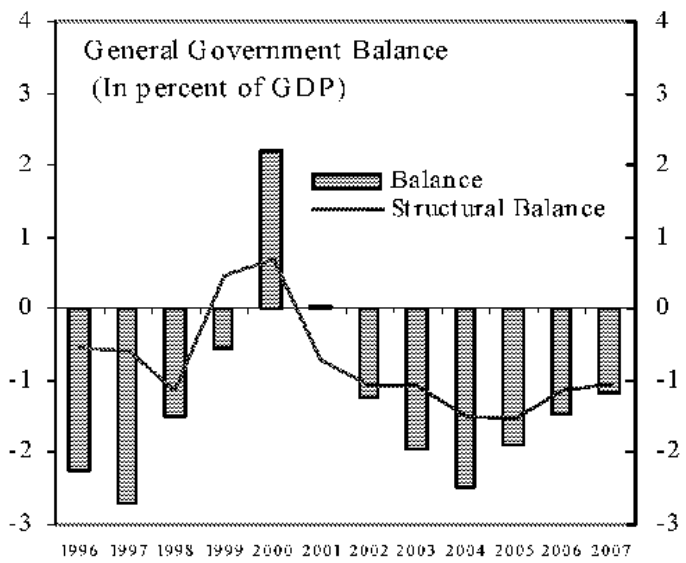
publicly guaranteed, pension funds.

\section{Staff agreed that the fiscal policy stance} was appropriate from a cyclical perspective. The authorities have allowed automatic stabilizers to operate fully and, to avoid jeopardizing the recovery, decided to eliminate the structural federal deficit only gradually (see next paragraph).

Moreover, cantonal and communal governments have been delaying corrective measures for revenue shortfalls pending clarification of the status of important tax measures in a referendum in May 2004 and agreement on the distribution of the proceeds from the sale of excess gold reserves. As a result, staff estimates a fiscal impulse of 0.4 percent of GDP in 2004 that will be withdrawn in subsequent years.

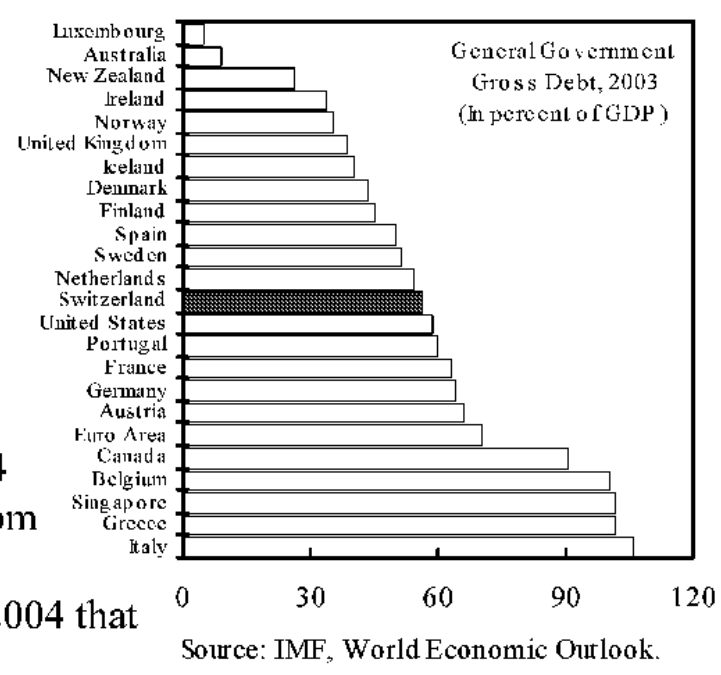

20. In its first two years of operation, the debt-brake ${ }^{4}$ has proven to be an effective instrument of ensuring fiscal discipline in a difficult economic environment. The

\footnotetext{
${ }^{4}$ The debt-brake rule requires the federal accounts to be in balance after adjusting for the business cycle. This is made operational by imposing a ceiling on expenditure that is equal to projected revenue scaled up by the ratio of trend-to-actual GDP. Unanticipated deficits must be reversed in the following years. The ceiling under the debt-brake rule can be over-ridden
} 
authorities explained that, contrary to initial estimates, shortfalls in the withholding tax and stamp duty revenue turned out to be permanent and led to a higher than originally thought structural federal deficit of almost 1 percent of GDP in 2003, at the time the debt-brake rule was introduced. The authorities underscored their commitment to the debt-brake rule and their intention to restore balance, largely with expenditure cuts. But, as large immediate expenditure cuts could have disrupted the provision of public services - and would have been undesirable from a cyclical perspective - the authorities adopted a graduated approach. First, they increased flexibility under the fiscal rule by (i) invoking an escape clause that allows them to spread the elimination of the structural deficit over several years - for credibility purposes a binding path was announced whereby the expenditure ceiling was raised by SwF 3 billion in 2004, SwF 2 billion in 2005 and SwF 1 billion in 2006 (respectively, 0.7 percent, 0.5 percent and 0.2 percent of GDP); and (ii) excluded from the calculation of the deficit transfers to/from the Unemployment Insurance Fund and an extraordinary capital injection of SwF 1.1 billion ( 0.25 percent of GDP) to the public employees' pension fund. ${ }^{5}$

Financial taxes have been declining in percent of GDP.

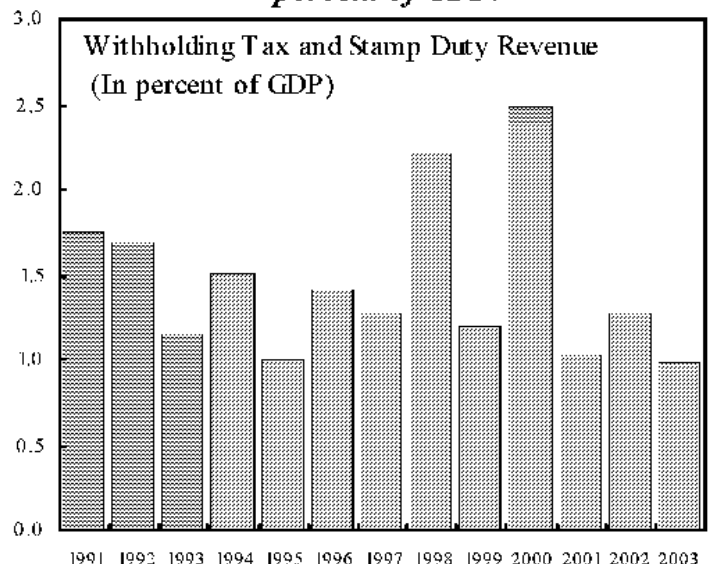

Consolidation Program 2003

(Cumulative improvement of fiscal balance over 2003-06 in billions SwF)

Expenditure cuts

o/w Public investment

Personnel

Early retirement schemes

Defence

Research and education

Agriculture

Housing

ODA

Revenue increases

o/w lobacco taxes

SNB profits

0.7
0.4
0.3
0.2
0.2
0.2
0.1
0.1
$\mathbf{0 . 5}$
0.2
0.2

21. The authorities noted that the debt-brake rule had proved instrumental in mobilizing parliamentary support for the measures aimed at restoring fiscal balance by 2007. The measures centered mainly on expenditure cuts (i) federal grants were cut by SwF 0.8 billion ( 0.2 percent of GDP), mainly by upholding the Confederation's share in the VAT increase; (ii) a consolidation program (Entlastungsprogramm 2003, EP2003) was adopted by parliament in December 2003 aimed at curtailing the federal deficit by

in exceptional circumstances if supported by a majority of members in both chambers of parliament. See IMF Country Report No. 01/75 for more details.

${ }^{5}$ Contingent liabilities related expenditure fall under the restrictions of the debt-brake, unless considered extraordinary by a qualified majority of parliament. 
SwF 3.3 billion ( $3 / 4$ percent of GDP) by 2006 ; and (iii) discussions have started for a second consolidation program (EP2004) of SwF 2.5 billion ( $1 / 2$ percent of GDP), targeted at balancing the federal budget in 2007. Staff argued that, to achieve the latter target, additional measures might well be needed to compensate for a possible erosion of the withholding tax and the stamp duty tax base. The authorities, while believing that the measures sufficed to achieve balance in 2007 , noted that they stood ready to take further action as needed.
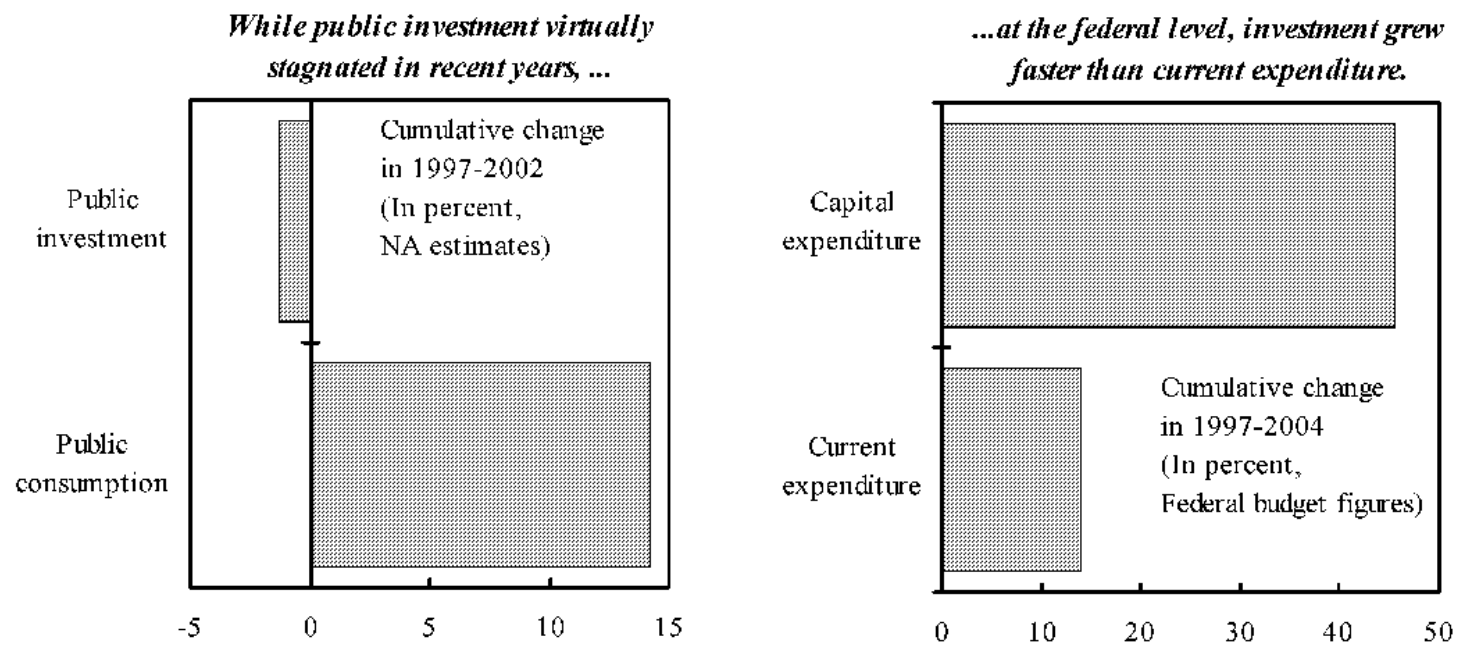

22. Staff fully supported the authorities' emphasis on expenditure cuts and advised greater reliance on curtailing current expenditure. Care must be taken that cuts in public expenditure do not fall disproportionately on investment, which could lead to the degradation of infrastructure, and, subsequently, lower growth. Staff noted that international experience suggests that spending cuts, especially in recurrent expenditure items, are generally lasting, whereas fiscal adjustments that rely primarily on tax increases and cuts in public investment are less successful in improving permanently public finances.

23. The debt-brake would benefit from some fine tuning. Staff acknowledged the communication advantages of using a simple filter in estimating cyclically adjusted revenue but believed that a model-based approach would had been more appropriate for the withholding tax and the stamp duty whose behavior is only loosely related to the business cycle. In the current formulation of the rule (derogations from the rule such as the delay eliminating the current structural deficit are not followed by offsetting surpluses) the debt ratio is susceptible to an upward drift. The authorities argued that increases in debt due to the recognition of contingent liabilities did not represent a deterioration in the underlying fiscal position. While acknowledging room for marginal improvements, the authorities were disinclined to revise the rule before gaining some additional experience from its implementation.

24. Looking ahead, the main challenge will come from pressures on the social security system. The authorities shared the view that in order to keep federal finances in balance in the long run, there was a need to increase contributions and/or curtail benefits. 
Staff welcomed plans to raise the VAT for financing social security and raise the retirement age and encouraged early action to address the rapid deterioration in the financial position of disability insurance and contain health care costs.

\section{Financial Sector: Coming Out of the Woods}

25. The authorities were optimistic that the worst from the recent financial market upheavals was over, but remained vigilant. Aggregate indicators of financial vulnerability are at comfortable levels and profits improved in 2003 (Table 3).

- In the case of banks, supervisors underscored that the sector had been adjusting successfully to shocks from the global economy and intensified domestic competition. Despite individual problems and the need for further consolidation, the sector remained robust and well capitalized. As a result, banks' equity prices have rebounded (Figure 9). In their quest for profitability, some banks have increased their risk appetite and credit has been expanding rapidly in some regions, but supervisors have been following the situation closely and noted that risk management had been strengthening and the share of collateralized loans increased. Banks weathered the Italian tax amnesty well, some shrinking of funds under management in banks in the Ticino region notwithstanding, and have been expanding their onshore presence to preserve their client base. The authorities did not believe that the implementation of the agreement with the EU on the taxation of income from savings would weaken Swiss banks'

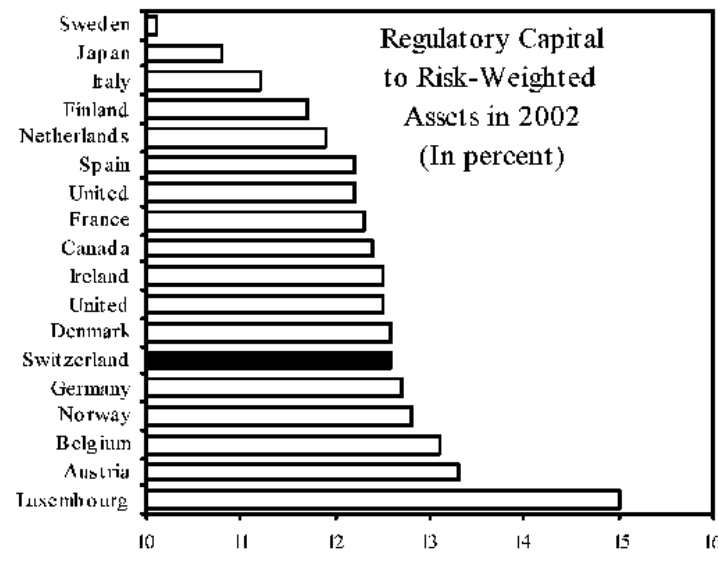
competitive position. Under the agreement (see also paragraph 29), Switzerland would maintain bank secrecy and, assuming timely adoption of the Directive, introduce a withholding tax on interest earnings of EU residents at a rate of 15 percent in 2005, 20 percent in 2008, and 35 percent in 2011, rates which do not exceed the current withholding tax. The EU Directive does not apply to dividends, which would support the expansion of investment fund activity.

- In insurance, financial conditions improved and supervisors were optimistic because the sector had strengthened corporate governance, cut costs, reduced exposures, improved risk management systems and refocused on core business. The sector had also been buoyed by the up-tick in equity prices and the reduction in the minimum interest rate on pension liabilities, although certain parameters in life insurance (e.g., the conversion rate) still did not fully reflect market conditions and demographics. Supervisors and market participants noted that, with the bulk of their 
portfolios in bonds, insurance companies could be squeezed by an unexpectedly rapid rebound in interest rates, improvements in their balance sheets notwithstanding.

The authorities acknowledged that, despite some improvement, the financial condition of pension funds remained strained. The number of under-funded pension funds (including public sector funds) increased from 6.5 percent at end-2001 to 20 percent at end-2002, with a shortfall equivalent to 10 percent of GDP. Under-funding appeared to have receded somewhat in 2003 following the recovery of equity prices. The authorities expected that, based on an extrapolation of recent trends, under-funding would be eliminated in two years, but under less optimistic scenarios it could take seven years. Meanwhile they have taken several measures to ameliorate the strain by: (i) reducing the minimum interest rate on pensioners' assets to $3 \frac{1 / 4}{4}$ percent in January 2003 and to $2 \frac{1 / 4}{4}$ percent in January 2004; (ii) introducing the possibility, in cases of under-funding, of raising contributions, temporarily suspending the minimum interest rate, and even introducing contributions from pensioners; and (iii) revising the occupational insurance law to gradually reduce the conversion ratethe rate at which accumulated savings are converted into pensions-from 7.2 to 6.8 percent. In addition, an experts group was considering revamping the currently fragmented supervisory framework for pension funds. Staff advocated the elimination of regulatory arbitrage in the second pillar and the creation of a level playing field for pension funds and insurance companies. Staff also cautioned that the lack of a general principle on the disclosure of liabilities and the considerable delay in compiling comprehensive statistics for the sector made it difficult to diagnose problems early and take prompt corrective action.

26. Steps have been taken to strengthen the regulatory and supervisory framework in line with the recommendations in the 2002 FSAP. The law for creating an integrated financial market supervisory authority, which initially will combine the operations of the Federal Banking Commission (EBK) and the Federal Office of Private Insurance, is being drafted. The revision of the Insurance Supervision Act, which, inter alia, aligned Swiss insurance regulation with EU directives, is expected to be finalized in 2004 . And the revision of the National Bank Law, which broadened the mandate of the SNB and expanded its instruments, entered into force in May of this year. Moreover, the SNB started publishing annually a financial stability report. To preserve Switzerland's reputation for efficient, transparent, and fair markets, the EBK has prepared a Code of Market Conduct. To improve external auditing, the EBK has prepared new circulars regarding auditing and reporting, started reviewing external auditors, and has increasingly been asking for second opinions from auditors. Finally, an expert group was set up to examine the compatibility of the Company Law with the Principles of Corporate Governance.

27. The authorities continued to strengthen anti-money laundering (AML) and the regime for combating the financing of terrorism (CFT). In 2003, a revised Money Laundering Ordinance covering the banking sector extended the application of AML instruments to the prevention of the financing of terrorism and required the systematic 
recording and computerized monitoring of all high-risk transactions; and a new Due Diligence Agreement strengthened the procedures of customer identification. The legal framework in place conforms broadly with the Financial Action Task Force's recommendations and steps are being taken to eliminate remaining discrepancies. The UN conventions for combating terrorist financing and related amendments to the Swiss Penal Code entered into force in 2003.

\section{E. Structural Issues: Invigorating Growth}

\section{There was agreement that raising medium-term growth is the main policy} challenge confronting Switzerland. Inefficiencies in sheltered domestic marketsprotection of agriculture and restrictive trade practices in network industries, construction and many services - keep costs and prices high and act as a drag on productivity (Figure 10). Staff pointed out that as other countries proceed in opening up markets and fostering competition, Switzerland risked falling behind as an attractive business location. The authorities shared this assessment but noted that the competencies of the federal government were not as strong as in unitary states and in the Swiss system of direct democracy, reform could not be imposed from above; broad-based support was needed to avoid negative referenda. Finally, hopes that the bilateral agreements with the EU would catalyze structural reform have not materialized.

29. Relations with the EU remains an actively debated issue. The authorities explained that EU membership entailed not only economic benefits but also costs and was seen as potentially undermining the much treasured system of direct democracy. They also thought that with bilateral agreements with the EU, Switzerland would achieve most of the benefits under the European Economic Area that was rejected in a referendum in 1992. With the electorate divided over the issue, membership is a distant possibility. Relations with the EU became strained after the mission following Switzerland's delay in ratifying the agreement on the taxation of income from savings pending negotiations on the remaining items of the second package of bilateral agreements.

30. In the wake of the rejection of the electricity bill in $2003,{ }^{6}$ the authorities have proposed a package of measures to promote growth through cautious structural reform. The rejection of electricity liberalization in a referendum was a major setback. The package of measures to promote growth is a collection of long-overdue reform projects. Staff

\footnotetext{
${ }^{6}$ The bill stipulated third-party access to the national grid and the phased opening of the market over a six-year period. The authorities explained that the public was concerned about distributional effects and alarmed by highly publicized blackouts in California; moreover, cantons' opposition stemmed from prospective tax revenue losses.
} 
agreed that the package provided feasible goals and synergies among the various reform measures that could raise GDP growth by at least $1 / 2$ percent annually in the medium term. ${ }^{7}$

31. Reform activity is concentrating in three main areas: antitrust, the Internal Market Act, and the deregulation of network industries.

- The revised antitrust law provides powerful tools to break up and deter cartels: horizontal and vertical price controls are declared illegal and subject to punitive fines. Staff agreed that demonstration effects from high-profile antitrust cases could have a beneficial effect on liberalization.

- The new Internal Market Act would create a uniform regulatory environment, and would centralize supervision. This could boost competition, increase consumer choice and lead to a decline in the price of many inputs and non-traded goods. Public procurement and professional services are, in many cases, regulated at the cantonal level, and the Federal Court has repeatedly protected local cartels and entry barriers from federal antitrust prosecution.

- The liberalization of network industries is proceeding slowly. The Federal Court has ruled that the distribution of electricity should be opened to competition, and negotiations between producers and large consumers have begun. The opening of local telephones is stalled in parliament, and liberalization of postal services and the railways remains incomplete. The authorities liberalized railway freight transport in 1999 , but the public carrier SBB retains 90 percent of the market and passenger transport continues to be heavily subsidized.

\section{F. Other Issues}

32. The authorities stated their commitment to multilateral trade liberalization. They regretted the failure of Cancun and supported the speedy resumption of negotiations; in this context, they organized an informal ministerial meeting at the World Economic Forum in Davos to discuss further negotiating objectives. Switzerland has a relatively open trade regime, with the exception of agriculture. ${ }^{8}$

\section{Staff was critical of the heavy protection and slow progress in opening up} agriculture. The mission noted that agricultural protection exceeded even EU levels. The average tariff on farm products is 34 percent (nearly four times the Swiss average), but is 300 percent on meat and almost 700 percent on some other agricultural goods. This is

\footnotetext{
${ }^{7}$ See IMF Country Report 02/107 and OECD 2003 Economic Review for Switzerland.

${ }^{8}$ Switzerland's rating on the IMF's $1-10$ scale of trade restrictiveness index is 4 ( 1 being the least restrictive), similar to that of most industrial countries.
} 
coupled with a system of direct producer support that, at 2 percent of GDP, is the highest among OECD countries and higher than even the value added of agriculture ( 1.5 percent of GDP). Staff noted that high food prices impose a heavy burden on consumers and tourism, where cost competitiveness is a major problem. The authorities argued that positive externalities on tourism and agriculture's central position in Swiss culture constrained the reform pace. They also noted that the distortionary price support system has declined from 100 to 60 percent of total support and a system of direct payments is being phased in. Production quotas on the important milk market have become tradable, leading to an increase in the average farm size. The abolition of milk quotas is envisaged for 2009 .

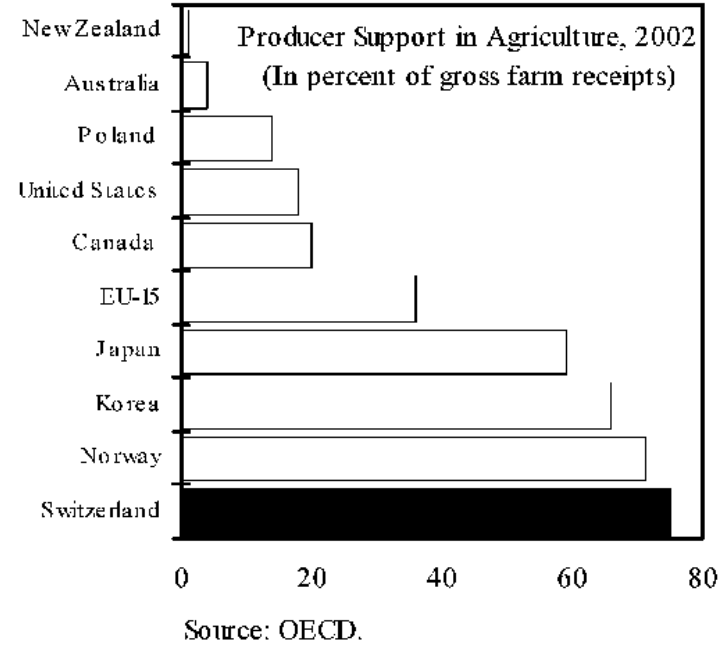

34. The authorities reaffirmed their intention to raise official development assistance (ODA) from 0.35 to 0.4 percent of GNP by 2010 , which is half the UN target. Swiss ODA policy has been favorably reviewed by the DAC for its effectiveness and its focus on poor countries. Also, Switzerland has eliminated custom duties on agricultural products from the tropics and reduced custom duties on imports from LDCs by $10-50$ percent in 2002 , a further 30 percent in 2004 , and plans to eliminate the remainder by 2007.

35. Swiss legislation conforms to the OECD Convention on anti-bribery. The requisite

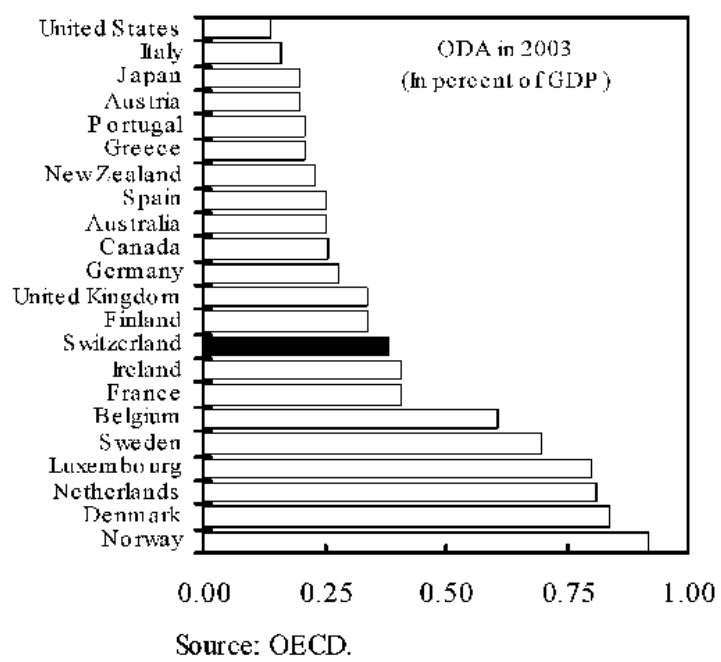
amendment to the Criminal Code regarding liability of legal entities came into force in 2003 .

36. Despite continuing improvement, deficiencies in the availability and quality of economic statistics remain (Appendix II). The authorities explained that budgetary constraints impeded more determined efforts to improve the quality and coverage of statistics.

\section{Staff Apprais 4 L}

\section{The authorities' renewed emphasis on long-overdue structural reforms is well}

placed. Switzerland has a robust external sector, flexible labor markets and sound monetary and fiscal policy frameworks. But slow progress in addressing structural rigidities in sheltered sectors has contributed to more than a decade of poor growth performance. The 
proposed package of measures, although modest, provides the right ingredients to revitalize growth.

38. In this regard, the enactment of the Competition Law is a positive first step. The provisions for fining and breaking up cartels and vertical restraints reflect international best practices. However, the effectiveness of the law is hampered by an inordinate amount of regulation at the lower levels of government. The authorities' plans to reform the internal market are welcome, and the creation of a leaner and uniform regulatory environment for products, network industries, and services across Switzerland should be a top priority.

39. In the short-term, the economy is well placed to benefit from the nascent global recovery. There are signs that the economy has started to grow, driven by a resilient external sector and supported by accommodative monetary and fiscal policies. Meanwhile, inflation is expected to remain very low in the near-term and, while brief episodes of negative inflation cannot be excluded, the prospects for damaging deflation seem to have receded.

40. With inflation expected to remain very low and activity below potential, the present stance of monetary policy is appropriate until the recovery is firmly secured. An early interest rate increase could jeopardize the recovery. At the same time, the current very low level of interest rates cannot be maintained indefinitely and, with liquidity building up rapidly, the monetary policy stance needs to be kept under constant review and modified proactively but without undue celerity.

41. The pragmatic approach to restoring fiscal balance is welcome. The transparent, realistic, and binding time-table for phasing out the unanticipated structural deficit helps preserve the credibility of the debt-brake and avoids procyclical reactions. While the overall fiscal position is relatively sound, additional measures could be needed beyond the amount in the 2004 consolidation plan if the structural decline in the withholding tax turns out to be higher than the current estimate. The bulk of the adjustment should be in carefully targeted expenditure cuts, focusing on current spending, rather than tax increases, which would jeopardize Switzerland's attractiveness as a business location.

\section{The state of the financial sector has improved but supervisors' continued} vigilance is well placed. Banks and insurance companies have undertaken considerable adjustments and the supervisory and regulatory environment is being improved. In this context, welcome steps are being taken to integrate banking and insurance supervision, increase resources for the supervisory authorities, and strengthen oversight of bank auditors. The anti-money-laundering ordinances that came into effect last year should further strengthen the reputation of Switzerland's financial sector.

43. Strains in the second pension pillar have subsided but some weaknesses remain. Conditions in the industry have been helped by the rebound in equity prices and the decrease in the minimum guaranteed interest rate. The authorities are encouraged to put in place a predictable rule-based mechanism in setting the minimum rate and take steps to strengthen supervision and eliminate regulatory arbitrage. 
44. The authorities are encouraged to spare official development assistance from budget cuts and urged to keep to their target of raising ODA to 0.4 percent of GDP by 2010. A faster pace of dismantling trade protection and subsidization of agriculture is necessary to underpin Switzerland's commitment to multilateral trade liberalization and as a contribution to help poor countries.

45. Additional resources need to be allocated for improving economic statistics. Gaps, deficiencies and delays, in some cases, hamper the quality of economic analysis and policy.

46. It is recommended that the next Article IV consultation with Switzerland be held on the standard twelve-month cycle. 


\section{Box 1: A Century of Real Appreciation for the Swiss Franc}

The traditional strength of the Swiss franc plays a key role in Switzerland's success as a financial center. The currency appreciated on average by $3 / 4$ percent per year in real effective terms over the past twenty years and has been accompanied by lower interest rates compared to the Euro or the US dollar. This sustained real appreciation, besides putting constant pressure for restructuring, has not disadvantaged the Swiss economy and was not a temporary misalignment, as attested by the longstanding current account surpluses.

The trend appreciation is not a recent phenomenon. IMF staff estimates show that the CPI-based real effective exchange rate and its equilibrium rate (FEER) have been appreciating, albeit in an uneven fashion, since the beginning of the twentieth century.

The reasons for the trend appreciation can be summarized as follows: Over the past century, Switzerland persistently saved more than its trading partners. This led to surpluses in the current account, which put upward pressure on the real exchange rate. In particular, four main factors accounted for surplus savings: (1) high savings of Swiss households relative to other countries; (2) a conservative fiscal policy and lower deficits than abroad; (3) favorable trends in the terms of trade, which have doubled over the past 100 years and increased the value of Swiss income; and (4) sheltered domestic markets with high

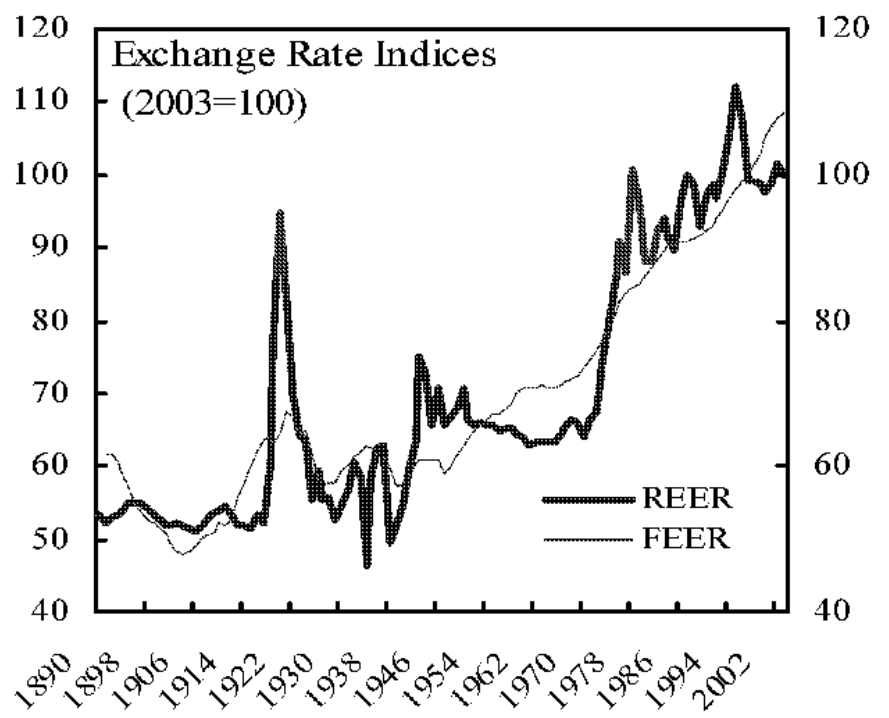
prices. Finally, the current account surpluses led to an accumulation of net foreign assets, which yield additional investment income from abroad.

The Bretton Woods system, with its fixed parities, appears as an interruption in the appreciation trend from the $1950 \mathrm{~s}$ to the mid-1970s. The Swiss franc was significantly undervalued, as the SNB accumulated reserves, but repressed inflation by imposing strict controls on credit and capital inflows. Once Switzerland abandoned the parity to the US dollar, the Swiss franc appreciated sharply, even overshooting its longer-run equilibrium. In recent years, the currency was again moving below its equilibrium, which would be consistent with large current account surpluses. 
Table 1. Switzerland: Basic Data

\begin{tabular}{|c|c|}
\hline \multicolumn{2}{|l|}{ Area and population } \\
\hline Total area & 41,293 square kilometers \\
\hline Total population (end-2002) & 7.2 million \\
\hline GDP per capita (2003) & $\$ 43,873$ \\
\hline GNI per capita (2003) & 46,075 \\
\hline
\end{tabular}

\begin{tabular}{|c|c|c|c|c|c|c|c|c|c|c|}
\hline & 1998 & 1999 & 2000 & 2001 & 2002 & 200311 & $20041 /$ & $20051 /$ & 200611 & 20071 \\
\hline & \multicolumn{10}{|c|}{ (Percentage clanges at constant prices) } \\
\hline \multicolumn{11}{|l|}{ Demand and supply } \\
\hline Total domestic demand & 4.1 & 0.3 & 2.2 & 1.9 & -0.9 & 0.1 & 2.2 & 1.9 & 2.0 & 1.8 \\
\hline Private consumption & 2.4 & 2.3 & 2.5 & 2,0 & 0.7 & 0.9 & 1.8 & 1.7 & 2.0 & 1.9 \\
\hline Public consumption & -0.9 & 0.3 & 2.4 & 4.0 & 0.8 & 0.9 & 1.6 & 1.5 & 1.0 & 1.0 \\
\hline Gross fixed investment & 6.4 & 1.0 & 4.3 & -3.1 & -4.9 & 0.0 & 3.3 & 3.2 & 2.4 & 2.4 \\
\hline Final domestic demand & 2.9 & 1.7 & 2.9 & 1.0 & -0.6 & 0.7 & 2.1 & 2.0 & 2.0 & 1.9 \\
\hline Inventory accumulation $2 /$ & 1.1 & -1.3 & -0.6 & 0.9 & -0.3 & -0.6 & 0.1 & -0.1 & 0.0 & -0.1 \\
\hline Foreign balance $2 t$ & -1.1 & 1.0 & 1.5 & -0.8 & 1.0 & -0.6 & -0.4 & 0.3 & 0.2 & 0.3 \\
\hline Exports of goods and nonfactor services & 3.9 & 6.5 & 12.2 & 0.2 & -0.5 & -1.4 & 3.4 & 5.0 & 5.3 & 5.5 \\
\hline limports of goods and nonfactor services & 7.5 & 4.3 & 9.5 & 2.2 & -3.1 & -0.1 & 4.8 & 4.9 & 5.4 & 5.5 \\
\hline GDP & 2.8 & 1.3 & 3.7 & 1.0 & 0.2 & -0.5 & 1.7 & 2.1 & 2.1 & 2.0 \\
\hline \multirow[t]{2}{*}{ GNP } & 2.9 & 1.7 & 5.2 & -1.8 & -1.7 & 0.5 & 1.9 & 2.5 & 2.1 & 2.4 \\
\hline & \multicolumn{10}{|c|}{ (In billions of SwF, at current prices) } \\
\hline \multirow[t]{2}{*}{ GDP } & 390.2 & 397.9 & 415.9 & 422.8 & 427.8 & 430.5 & 441.3 & 455.2 & 469.9 & 485.5 \\
\hline & \multicolumn{10}{|c|}{ (In thousands, unless otherwise indicated) } \\
\hline \multicolumn{11}{|l|}{ Employment and unemployment } \\
\hline Employment & 3,841 & 3,867 & 3,915 & 3,974 & 3,990 & 3,978 & 4,024 & 4.057 & 4,097 & 4.133 \\
\hline (Percent cliangse) & -3.0 & 0.7 & 1.2 & 1.5 & 0.4 & -0.3 & 1.1 & 0.8 & 1.0 & 0.9 \\
\hline Unemployment rate (in percent) & 3.9 & 2.7 & 1.8 & 1.7 & 2.5 & 3.7 & 3.4 & 3.2 & 2.9 & 2.6 \\
\hline Output gap (in percent of potential) & -1.5 & -1.6 & 0.1 & -0.1 & -0.9 & -2.3 & -1.8 & -0.9 & -0.4 & -0.1 \\
\hline \multicolumn{11}{|l|}{ Prices and incomes } \\
\hline GDP deflator & -0.3 & 0.7 & 0.8 & 0.6 & 1.0 & 1.2 & 0.8 & 1.0 & 1.1 & 1.3 \\
\hline Consumer price index & 0.0 & 0.8 & 1.6 & 1.0 & 0.5 & 0.6 & 0.3 & 0.4 & 1.2 & 1.5 \\
\hline No1ninal wage growtl & 0.7 & 0.3 & 1.3 & 2.5 & 1.8 & 0.8 & 0.9 & 1.8 & 2.5 & 2.6 \\
\hline Unit labor costs (total economy) & -0.8 & 0.5 & 0.8 & 3.0 & 2.1 & 1.1 & 0.3 & 0.5 & 1.4 & 1.5 \\
\hline & \multicolumn{10}{|c|}{ (In percent of GDI) } \\
\hline \multicolumn{11}{|l|}{ Public finances } \\
\hline \multicolumn{11}{|l|}{ General goverwment } \\
\hline Revenue & 37.8 & 36.5 & 38.3 & 37.3 & 37.1 & 37.3 & 37.0 & 37.2 & 37.2 & 37.2 \\
\hline Expenditure & 38.2 & 37.1 & 36.1 & 37.2 & 38.4 & 39.2 & 39.5 & 39.1 & 38.7 & 38.4 \\
\hline Financial balance $3 i$ & -0.4 & -0.6 & 2.2 & 0.0 & -1.2 & -1.9 & -2.5 & -1.9 & -1.5 & -1.2 \\
\hline Structural balance $4 /$ & -7.6 & 0.5 & 0.7 & -0.7 & -1.1 & -1.1 & -1.5 & -1.5 & -1.1 & -1.0 \\
\hline Gross debt & 53.1 & 50.2 & 49.9 & 50.5 & 54.9 & 55.6 & 56.2 & 56.3 & 56.0 & 55.4 \\
\hline \multicolumn{11}{|l|}{ Central government } \\
\hline Ruvenue & 12.1 & 10.8 & 12.5 & 11.7 & 12.0 & 11.0 & 11.0 & 11.4 & 11.4 & 11.5 \\
\hline Expenditure & 12.0 & 11.6 & 11.6 & 12.1 & 12.1 & 11.9 & 12.3 & 12.2 & 12.0 & 11.9 \\
\hline Balance 3/ & 0.0 & -0.8 & 0.9 & -0.4 & -0.1 & -0.9 & -1.3 & -0.8 & -0.7 & -0.5 \\
\hline Gross debt & 27.0 & 24.7 & 25.3 & 25.1 & 28.7 & 28.7 & 29.3 & 29.2 & 28.9 & 28.5 \\
\hline
\end{tabular}

1/ Fund starl estimates and projections unless otherwise noted.

2/ Change as percent of previous year's GDP.

3/ Including railway loans as expenditure.

4/ Excluding privatization proceeds; smooths erratic revenue items. 
Table 1. Switzerland: Basic Data (concluded)

\begin{tabular}{|c|c|c|c|c|c|c|c|c|c|c|}
\hline & 1998 & 1999 & 2000 & 2001 & 2002 & $20031 /$ & $20041 t$ & $20051 t$ & $2006 \mathrm{l} /$ & $20071 /$ \\
\hline & \multicolumn{10}{|c|}{ (In billions of SwF, unless otherwise indicated) } \\
\hline \multicolumn{11}{|l|}{ Balance of payments } \\
\hline Irade balance & -2.3 & -0.3 & -4.2 & $-4,6$ & 5.2 & 4,6 & 2.9 & 2.2 & 1.8 & 1.4 \\
\hline Service balance & 19.6 & 21.6 & 25.6 & 22.1 & 22.1 & 23.2 & 21.4 & 22.5 & 22.7 & 2.3 .2 \\
\hline Net investment income & 32.4 & 37.0 & 43.5 & 34.0 & 24.8 & 31.9 & 33.4 & 36.1 & 38.4 & 40.3 \\
\hline Net compensation of employees & -6.4 & -6.5 & -7.8 & -8.6 & -9.2 & -10.3 & -10.0 & -10.0 & -10.0 & -10.0 \\
\hline Net private transfers & -3.1 & -3.9 & -3.3 & -4.9 & -4.2 & -3.0 & -3.1 & -3.1 & -3.1 & -3.2 \\
\hline Net official transfers & -2.3 & -2.3 & -1.7 & -1.8 & -2.3 & -2.3 & -2.3 & -2.4 & -2.4 & -2.5 \\
\hline Current account & 37.8 & 45.7 & 52.2 & 36,1 & 36.4 & 44,0 & 42.3 & 45.3 & 47.4 & 49.2 \\
\hline (In percent of GDP) & 9.7 & 11.5 & 12.5 & 8.5 & 8.5 & 10.2 & 9.6 & 10.0 & 10.1 & 10.1 \\
\hline Foreign direct investment & -14.2 & -32.4 & -42.9 & -15.9 & -3.0 & 1.7 & $\ldots$ & $\ldots$ & $\ldots$ & $\ldots$ \\
\hline Outward & -27.2 & -50.0 & -75.4 & -30.9 & -11.8 & -14.7 & $\ldots$ & $\ldots$ & $\ldots$ & $\ldots$ \\
\hline Inward & 13.0 & 17.6 & 32.5 & 15.0 & 8.8 & 16.4 & $\ldots$ & $\ldots$ & $\ldots$ & $\ldots$ \\
\hline Portfolio investment & -6.7 & -61.5 & -19.9 & -69.1 & -35.2 & -47.0 & $\ldots$ & $\ldots$ & $\ldots$ & $\ldots$ \\
\hline Outward & -21.6 & -70.4 & -37.7 & $-72,3$ & -46.6 & -44.5 & $\ldots$ & $\cdots$ & $\ldots$ & $\ldots$ \\
\hline Inward & 14.9 & 8.9 & 17.8 & 3.2 & 11.4 & -2.5 & $\ldots$ & $\ldots$ & $\ldots$ & $\ldots$ \\
\hline Banking sector, net & -16.7 & 27.5 & 11.0 & 18.5 & -32.4 & -10.6 & $\cdots$ & $\cdots$ & $\cdots$ & $\cdots$ \\
\hline \multicolumn{11}{|l|}{ Memorandum items: } \\
\hline Net investment income & 32.4 & 37.0 & 43.5 & 34.0 & 24.8 & 31.9 & $\ldots$ & $\ldots$ & $\ldots$ & ... \\
\hline (In percent of GDl') & 8.3 & 9.3 & 10.5 & 8.0 & 5.8 & 7.4 & $\ldots$ & $\cdots$ & $\cdots$ & $\cdots$ \\
\hline Net external assets & 492,3 & 572.5 & 521.5 & 586,0 & 599.2 & 664.0 & $\ldots$ & $\cdots$ & $\ldots$ & $\ldots$ \\
\hline (lin percent of GDP) & 126.2 & 143.9 & 125.4 & 138,6 & 140.1 & 154.3 & $\ldots$ & $\ldots$ & $\ldots$ & $\ldots$ \\
\hline Official reserves (billions of US\$, end period) $2 /$ & 41.2 & 36.3 & 32.3 & 32.0 & 40.2 & 47.6 & 49.8 & $\ldots$ & $\ldots$ & $\ldots$ \\
\hline Reserve cover (montles of imports of GNFS) 2/ & 4.9 & 4.9 & 3.8 & 3.7 & 4.5 & 4.6 & 4.6 & $\ldots$ & $\ldots$ & $\ldots$ \\
\hline & \multicolumn{10}{|c|}{ (Percentuge changes in annut averayes) } \\
\hline \multicolumn{11}{|l|}{ Monetary and credit data $3 i$} \\
\hline Money (M1) & 8.8 & 9.4 & -3.1 & 0.6 & 9.1 & 27.9 & 32.2 & $\ldots$ & $\ldots$ & $\ldots$ \\
\hline Broad money (M3) & 1.2 & 1.0 & -1.8 & 3.1 & 3.8 & 8.4 & 7.9 & $\ldots$ & $\ldots$ & $\ldots$ \\
\hline \multirow[t]{2}{*}{ Domestic credit } & 0.5 & 3.2 & 1.7 & 1.5 & -0.5 & 0.6 & 1.9 & $\ldots$ & $\ldots$ & $\ldots$ \\
\hline & \multicolumn{10}{|c|}{ (Period averages in percent) } \\
\hline \multicolumn{11}{|l|}{ Interest rates $4 i$} \\
\hline Three-month rate & 1.6 & 1.4 & 3.1 & 2.9 & 1.2 & 0.3 & 0.3 & $\ldots$ & $\ldots$ & $\ldots$ \\
\hline Yield on government bonds & 2.9 & 2.9 & 3.8 & 3.3 & 3.1 & 2.5 & 2.5 & $\ldots$ & $\ldots$ & $\ldots$ \\
\hline \multicolumn{11}{|c|}{ (Levels) } \\
\hline \multicolumn{11}{|l|}{ Exchange rates } \\
\hline SwF per IJS\$ (end of period) 5 & 1.38 & 1.60 & 1.63 & 1.65 & 1.44 & 1.26 & 1.30 & $\ldots$ & $\ldots$ & $\ldots$ \\
\hline SwF per US \$ (annnal average) $5 i$ & 1.45 & 1.50 & 1.69 & 1,69 & 1.56 & 1,36 & 1.30 & $\ldots$ & $\ldots$ & $\ldots$ \\
\hline SwF per euro (annual average) $5 /$ & 1.61 & 1.60 & 1.56 & 1.51 & 1.48 & 1.51 & 1.55 & $\ldots$ & $\ldots$ & $\ldots$ \\
\hline Nominal effective rate $(1990=100) 3 i$ & 107.1 & 106.0 & 105.1 & 109.2 & 113.6 & 113.2 & 110.7 & $\ldots$ & $\cdots$ & $\ldots$ \\
\hline Real effective rate $(1990=100) 3 / 6 /$ & 102.1 & 100.2 & 97.8 & 100.7 & 104.4 & 104.0 & 102.0 & $\ldots$ & $\ldots$ & $\ldots$ \\
\hline
\end{tabular}

Sources: IMF, World Economic Outlook databuse; Swiss National Bunk; and Swiss Institute for Business Cycle Research.

1/ Fund staff estimates and projections unless otherwise noted

2/ Data for 2004 refer to January.

3/ Data for 2004 refer to lebruary,

4/ Data for 2004 refer to March.

5/ Data for 2004 refer to April 13.

6/ Based on relative consumer prices. 
Table 2. Switzerland: Fiscal Projections

\begin{tabular}{|c|c|c|c|c|c|c|}
\hline & \multicolumn{2}{|c|}{ Oullurn } & \multicolumn{4}{|c|}{ Projections $^{1 /}$} \\
\hline & 2002 & 2003 & 2004 & 2005 & 2006 & 2007 \\
\hline & \multicolumn{6}{|c|}{ (ln percentage of GDP) } \\
\hline Federal government balance $^{2 /}$ & -0.1 & -0.9 & -1.3 & -0.8 & -0.7 & -0.5 \\
\hline Cantonal governments balance & -0.1 & -0.6 & -0.5 & -0.7 & -0.5 & -0.4 \\
\hline Communal governments balance & 0.2 & -0.2 & -0.2 & -0.4 & -0.3 & -0.2 \\
\hline Social Funds ${ }^{3 /}$ & -0.4 & -0.3 & -0.5 & -0.1 & -0.1 & 0.0 \\
\hline General government balance & -1.2 & -1.9 & -2.5 & -2.0 & -1.6 & -1.2 \\
\hline Privatization proceeds & 0.9 & 0.0 & 0.0 & 0.0 & 0.0 & 0.0 \\
\hline Balance excluding privatization proceeds & -2.1 & -1.9 & -2.5 & -2.0 & -1.6 & -1.2 \\
\hline Structural balance ${ }^{4 /}$ & -1.1 & -1.0 & -1.5 & -1.5 & -1.2 & -1.0 \\
\hline Fiscal impulse ${ }^{3 i}$ & 0.3 & -0.1 & 0.5 & 0.1 & -0.3 & -0.1 \\
\hline \multicolumn{7}{|l|}{ Memorandum items: } \\
\hline Structural federal deficit ${ }^{6 t}$ & -0.9 & -0.5 & -0.7 & -0.4 & -0.2 & 0.0 \\
\hline Measures as a \% of GDP (Consolidation Plan 2003) & $\ldots$ & $\ldots$ & 0.2 & 0.5 & 0.7 & $\ldots$ \\
\hline Output gap & -0.9 & -2.3 & -1.8 & -0.9 & -0.4 & -0.1 \\
\hline General government revenue increase, in percent & 0.7 & 1.1 & 1.4 & 3.9 & 2.8 & 3.1 \\
\hline General government expenditure increase, in percent & 4.2 & 2.9 & 2.9 & 2.4 & 1.9 & 2.1 \\
\hline
\end{tabular}

Source: Ministry of Finance and IMF staff estimates and projections

1/ Includes large railway projects and ETH-related expenditure.

2/ Federal expenditure are based on the 2004 budget and the 2005-2007 rinancial Plan. Includes saving measures of 0.7 percent of GDP (Consolidation Plan 2003), but not measures under discussion (Consolidation Plan 2004). Federal revenue are based on the current financial plan, adjusted for the TMF staff's macroeconomic projections; projections take into account the impact of the 2001 family package. Cantonal and communal balances are based on the current financial plan. Social finds are based on Minister of Hinance data, adjusted for the IMF staff's macroeconomic projections.

3/ Social funds include the old age, disability and survivors protection schemes (AHV, FV), and unemployment and income loss insurance (ALV, EO). Following ESA95 conventions, the Swiss accident insurance (SUVA) is no longer in the public sector. 4/ Excludes privatization proceeds, smoothes erratic revenue items, and adjusts the effect of the business cycle.

$5 /$ Negative of the change in the structural balance.

6/ Ministry of Finance. 
Table 3. Switzerland: Indicators of External and Financial Vulnerability (In percent of GDP, unless otherwise indicated)

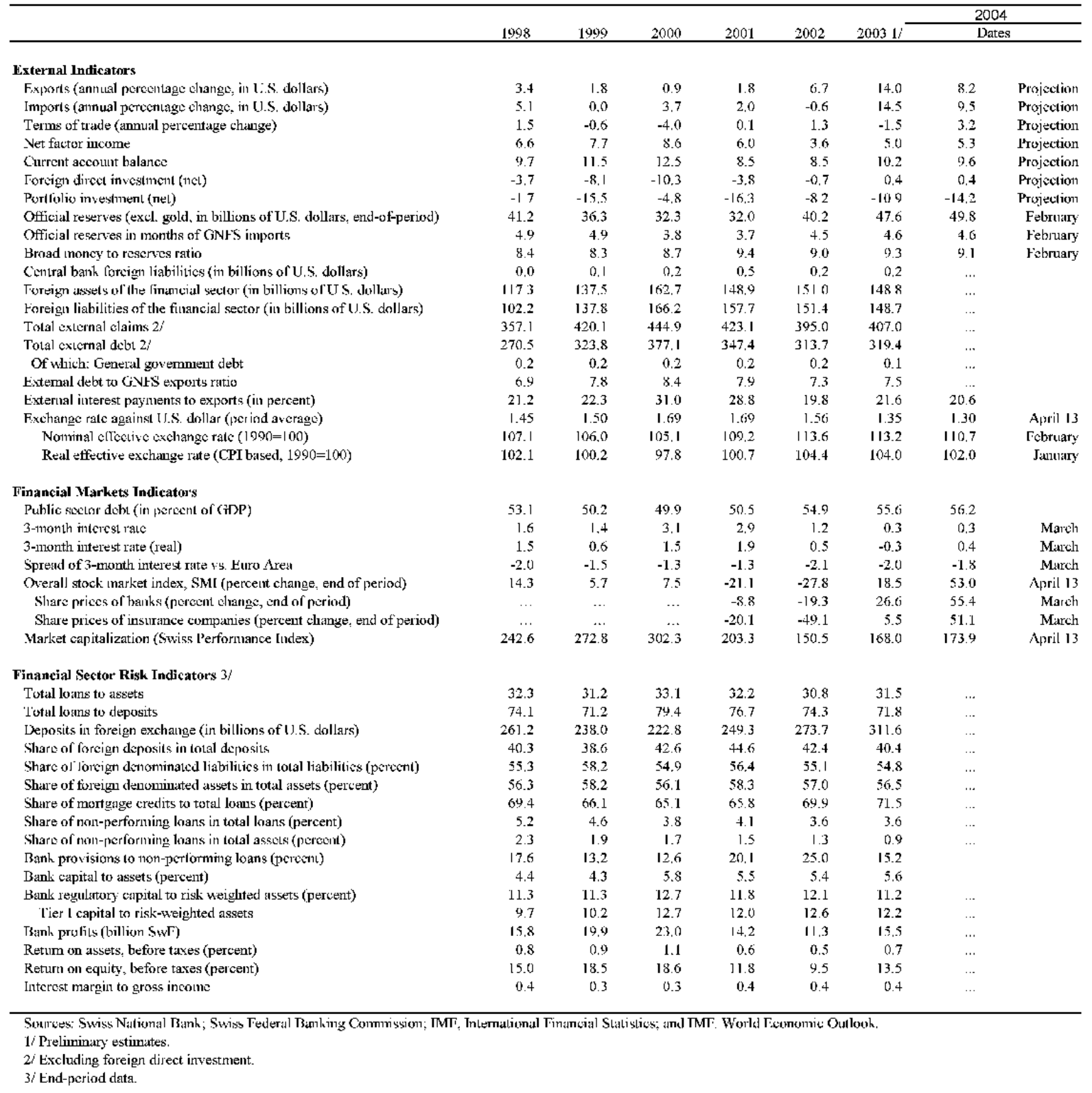


Figure 1. Main Economic Indicators in International Perspective, 2001-2003

(In percent)

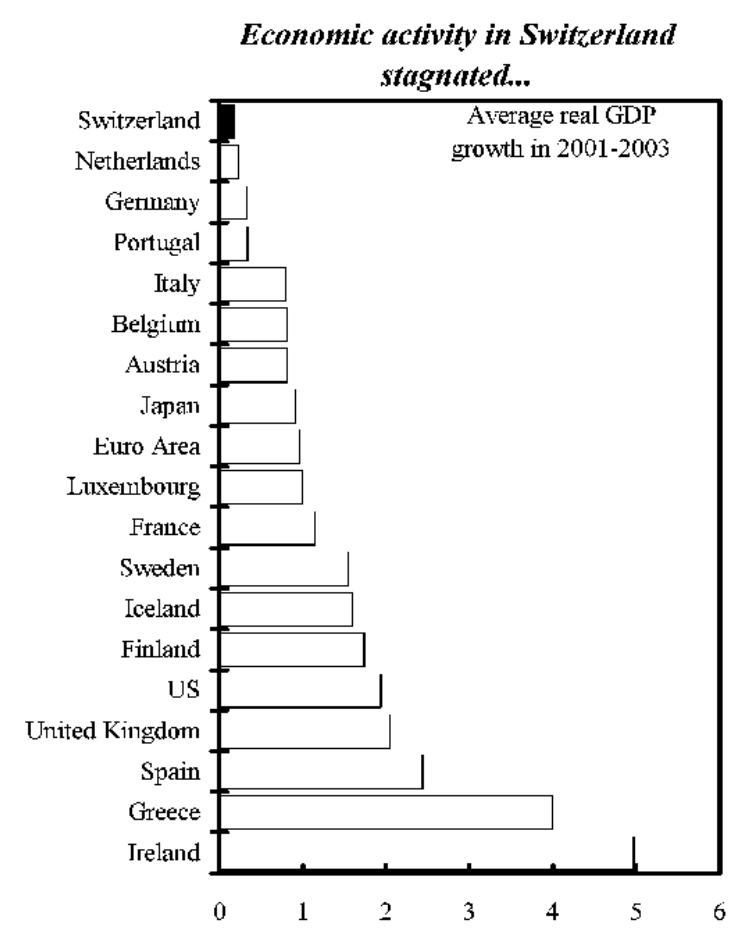

Unemployment...

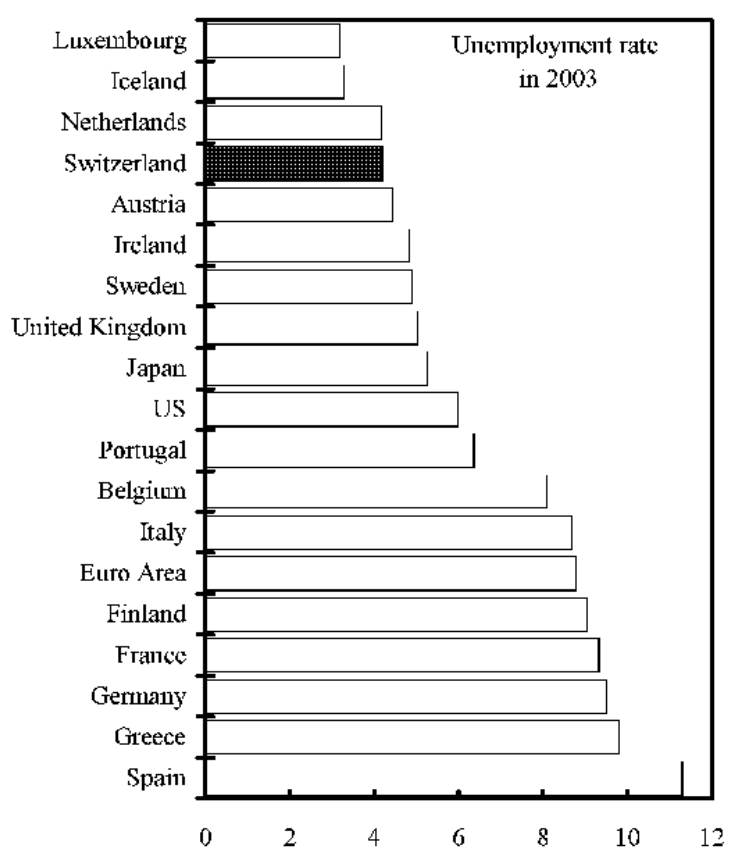

Source: IMF, World Economic Outlook.

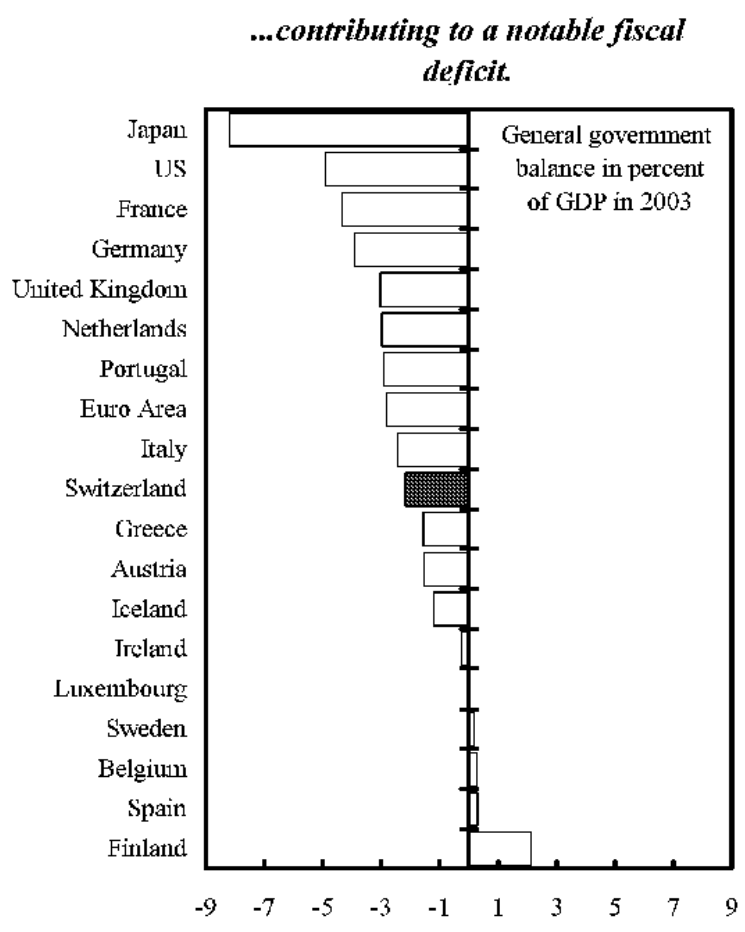

....and inflation remain low.

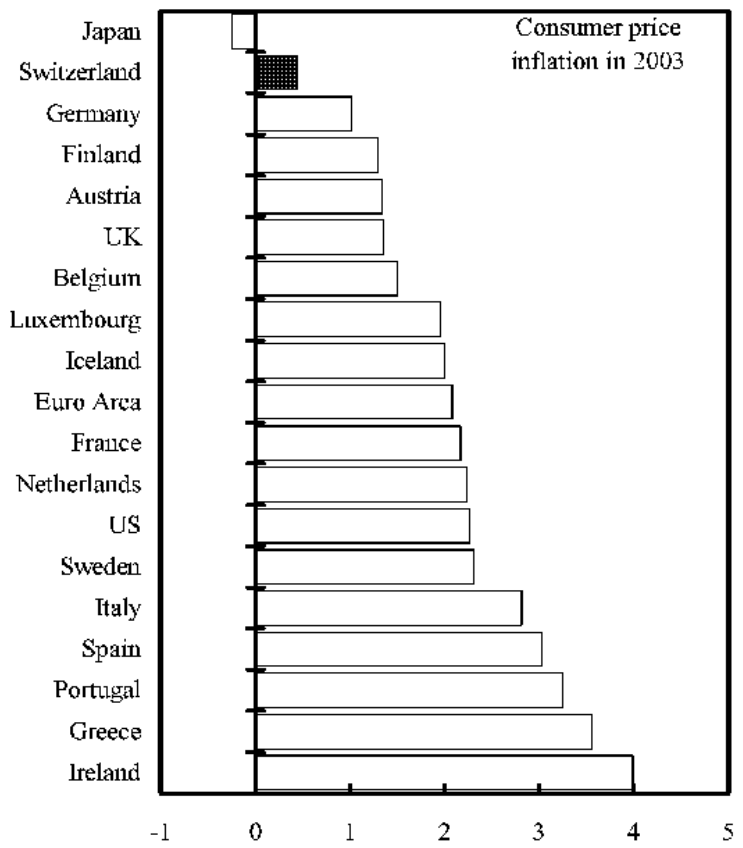


Figure 2. Switzerland: GDP and its Components 1/

The current slowdown has been deeper than in EU and Germany...

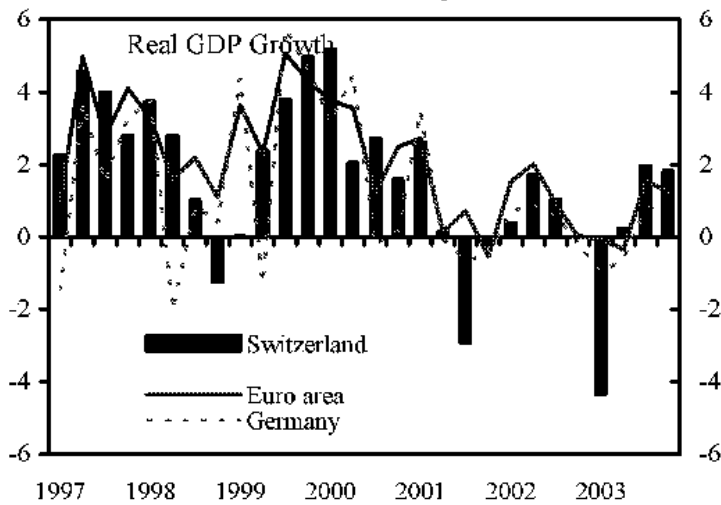

Investment has dropped...

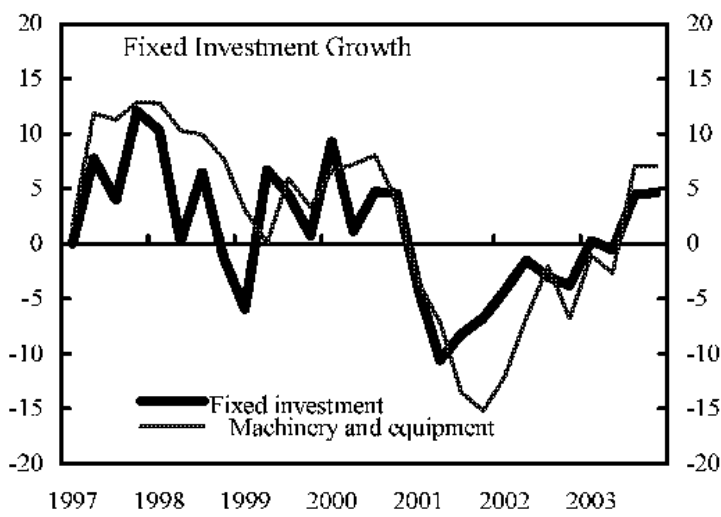

Export growth has weakened..

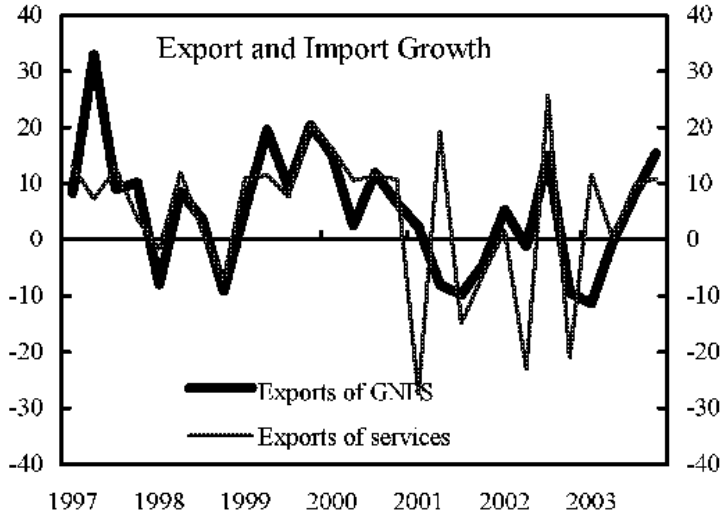

...and comparable to the record-long recession of $1990^{\prime}$ 's.

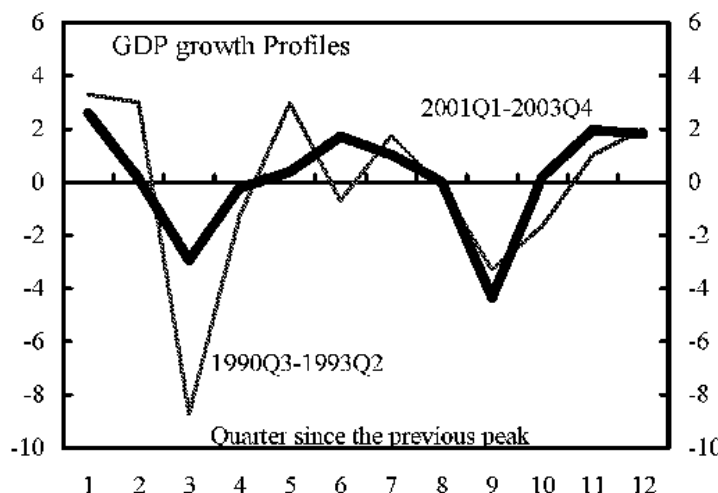

...more than in previous cycles.

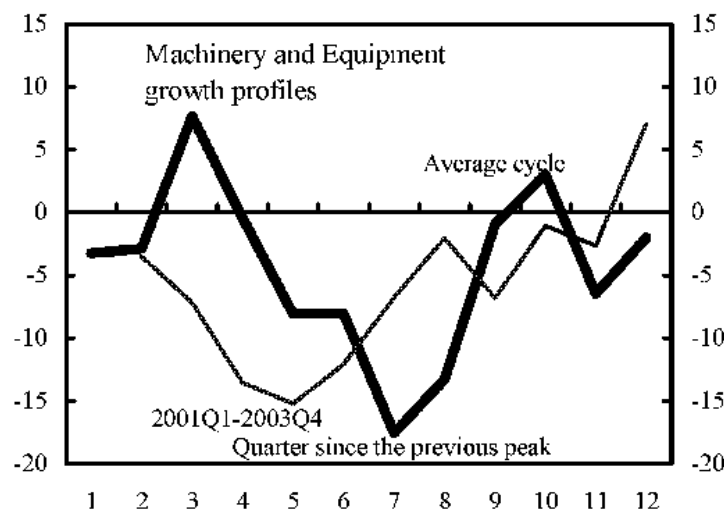

...in line with the global slowdown.

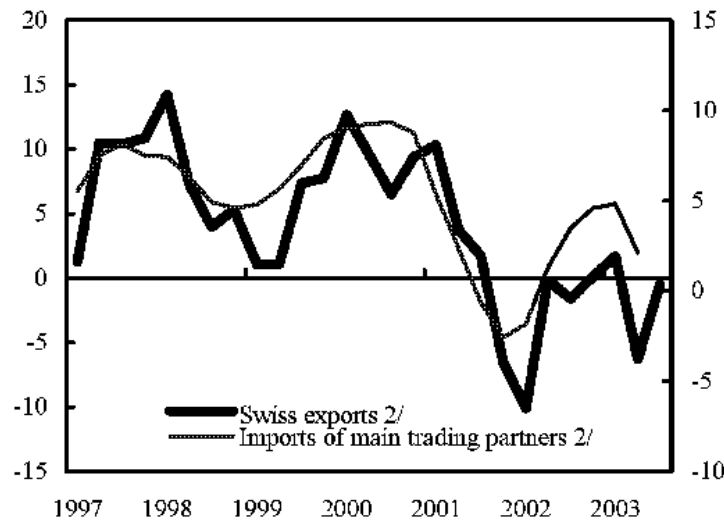

Source: IMF, World Economic Outlook.

$1 /$ Seasonally adjusted annualized rates, unless otherwise indicated.

2/ Year-on-year percent change. 
Figure 3. Switzerland: Labor Market Developments

With unemployment up morkedly...

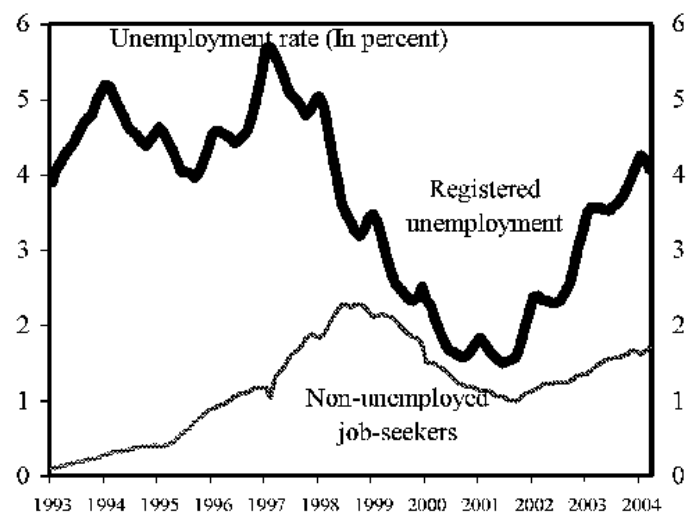

Employment contracted in 2003.

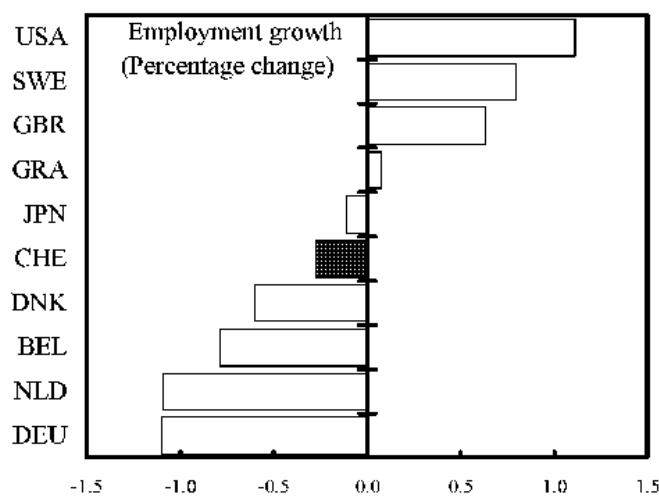

... working hours ....

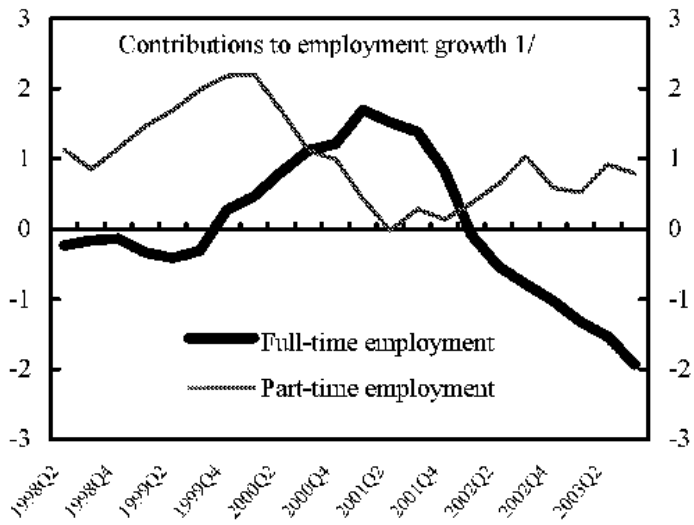

... shortages of skilled labor are no longer a problem.

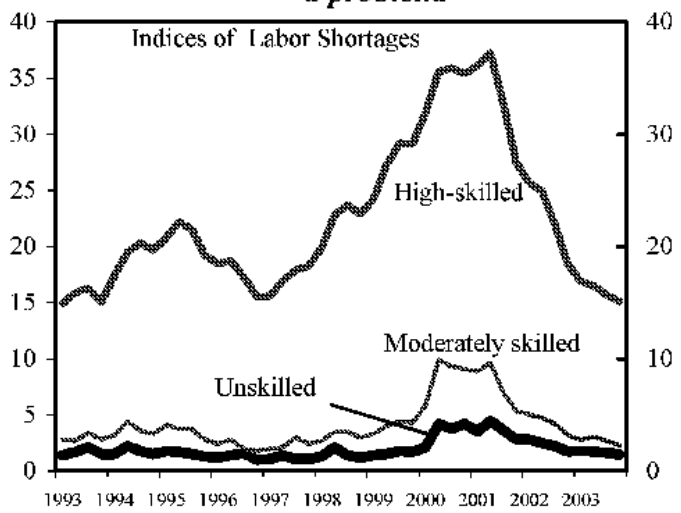

Adjustment has taken place mainly in manufacturing...

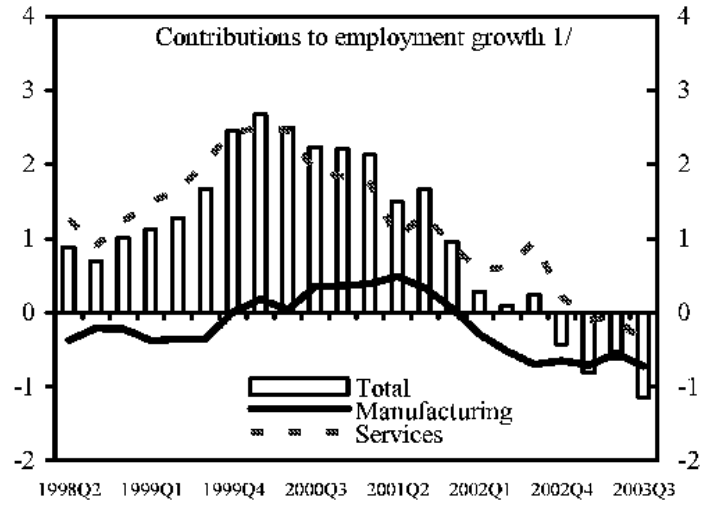

... and foreign employment.

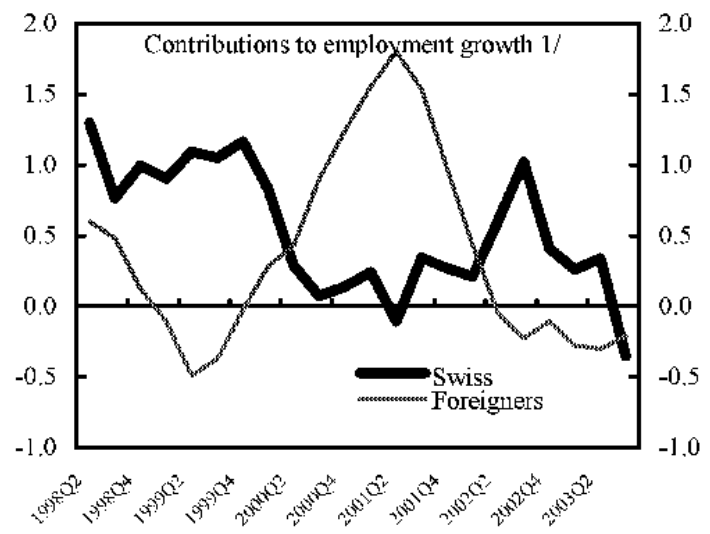

Sources: IMF, World Economic Outlook; and KOF Institute.

$1 /$ Year-on-year percent change. 
Figure 4. Switzerland: Inflation Has Been and Is Expected to Remain Low

Consumer inflation has been low...

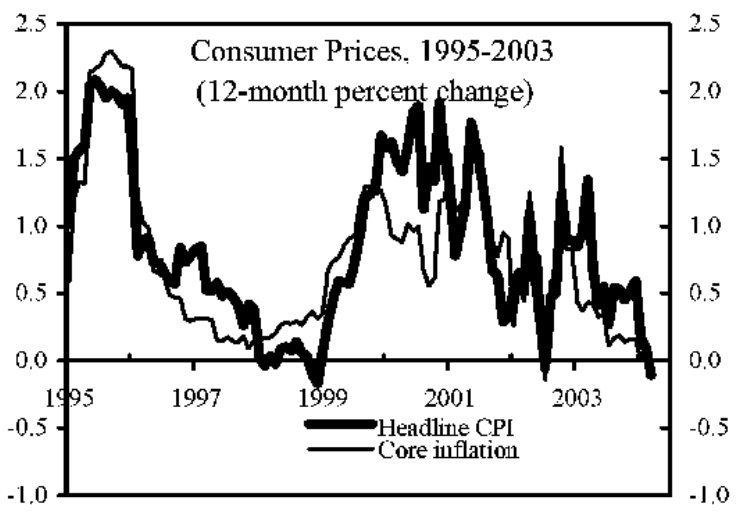

...and declining domestic inflation...

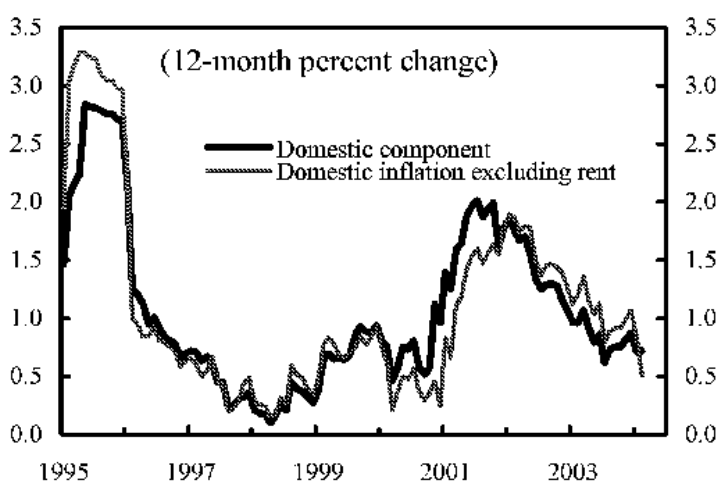

Producer prices have been declining.

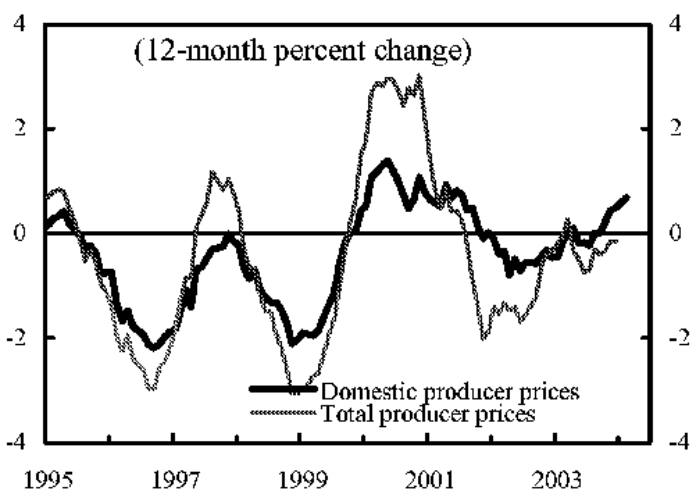

Source: KOF database. ...driven by declining imported goods prices...

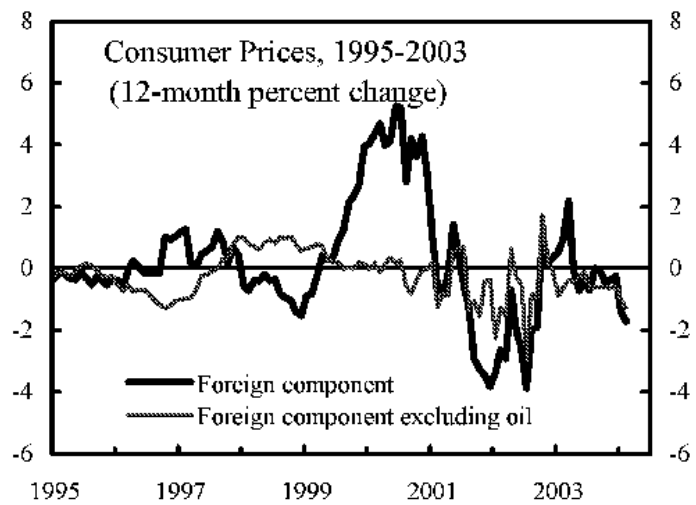

...despite moderate inflation in sheltered sectors like education and health.

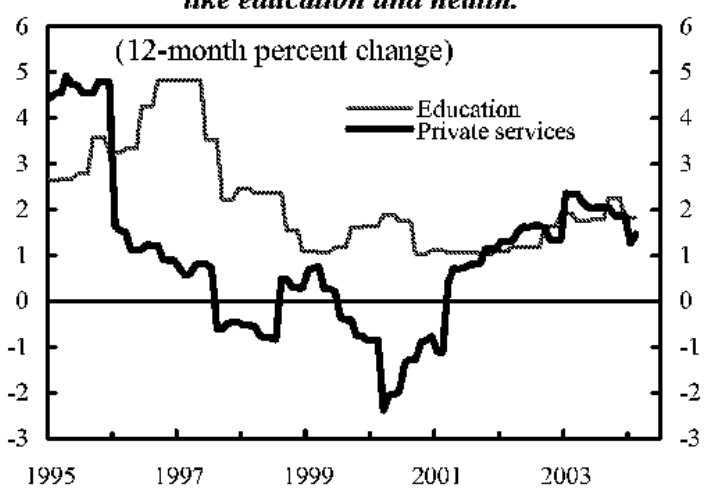

SNB expects inflation to remain low

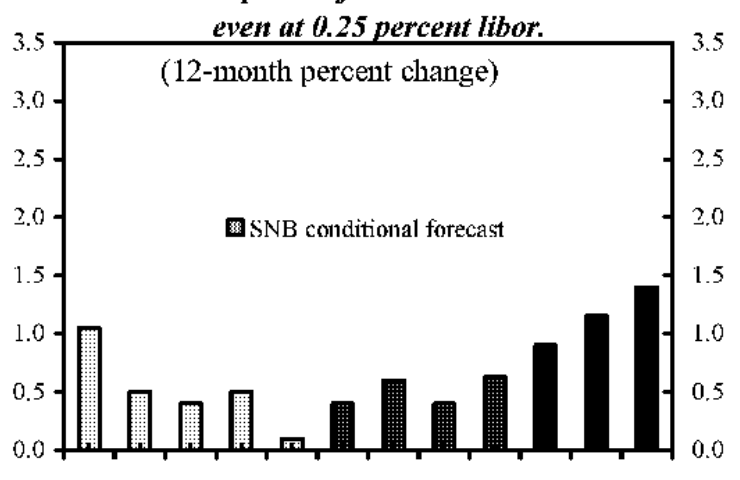

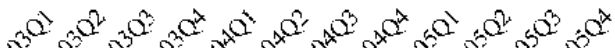

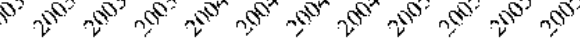


Figure 5. Switzerland: Monetary Conditions Have Eased

Aggressive interest rate cuts..

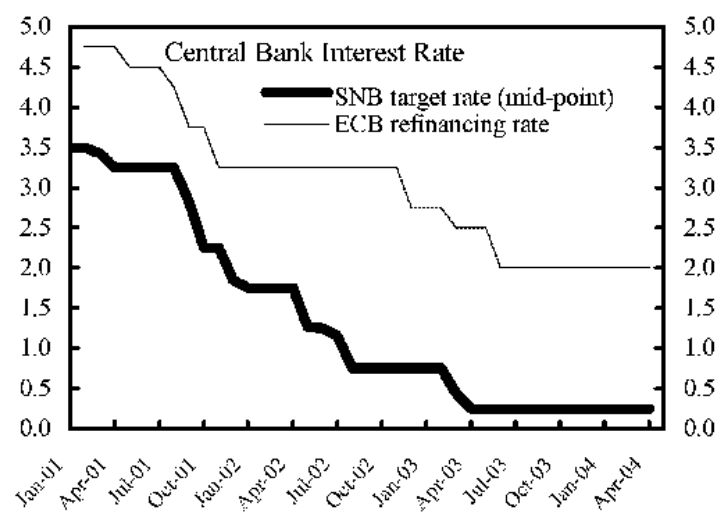

...but the steepening of the yield curve...

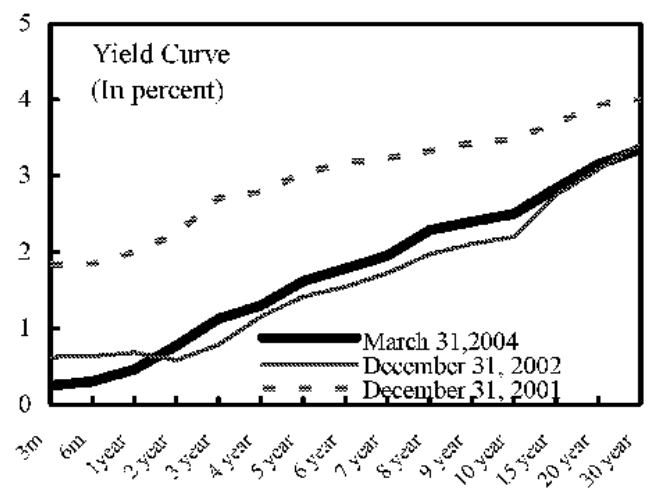

...have moderated the decline in real borrowing costs.

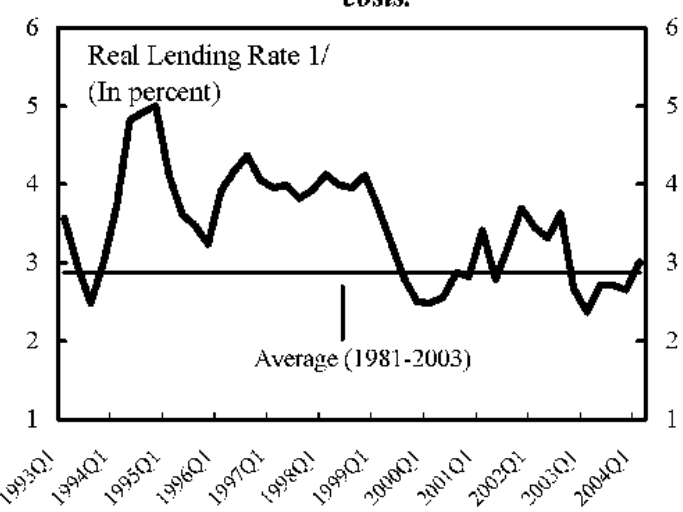

...have reduced short-term nominal interest rates to historic lows...

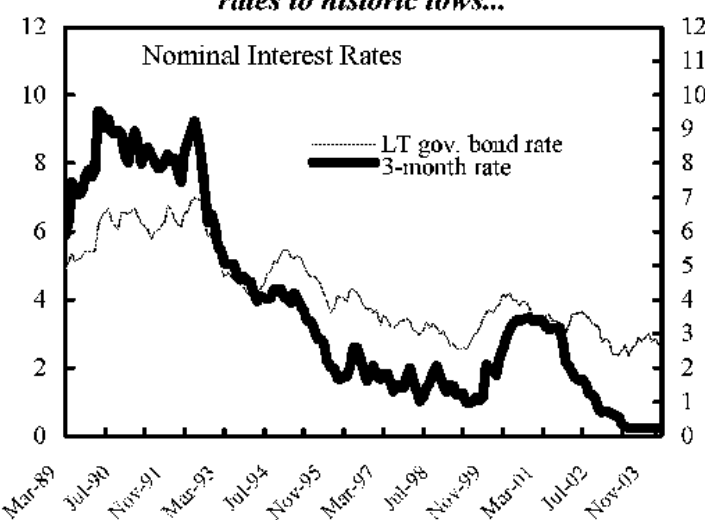

...and the widening of intermediation spread...

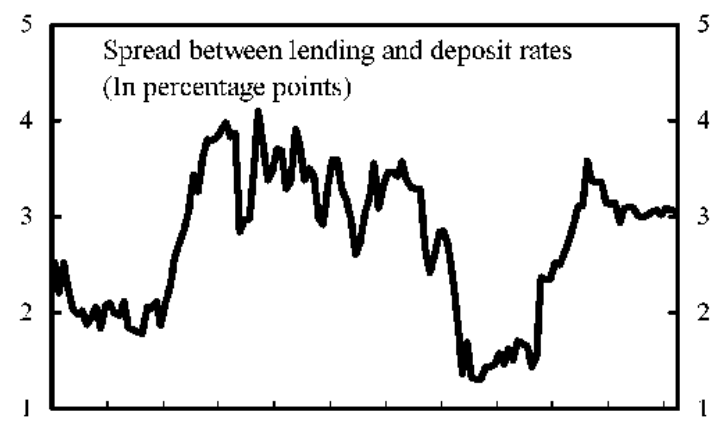

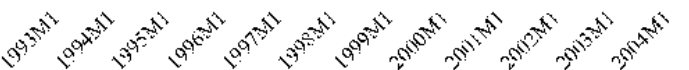

The franc has weakened recently.

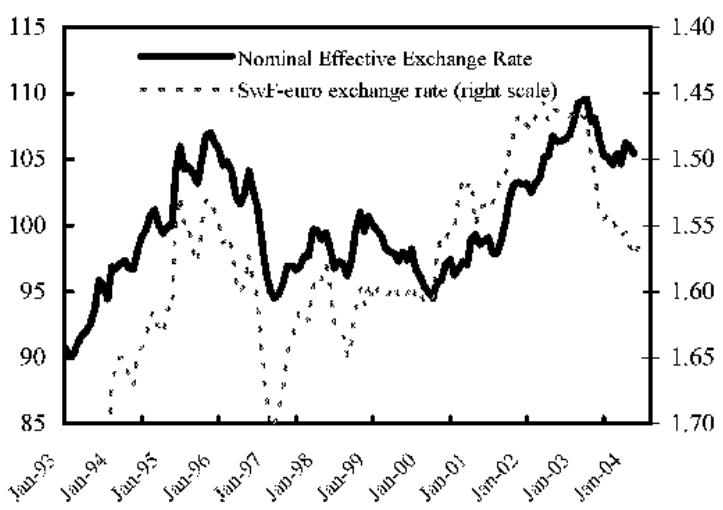

Source: KOF database; Bloomberg; and IMF, International Financial Statistics and IMF staff estimates.

1/ Actual rates minus 12-month change in CPI index. 
Figure 6. Switzerland: Assets Prices Have Recovered

Equity prices recovered but remain jittery, mirroring movements in global markets....

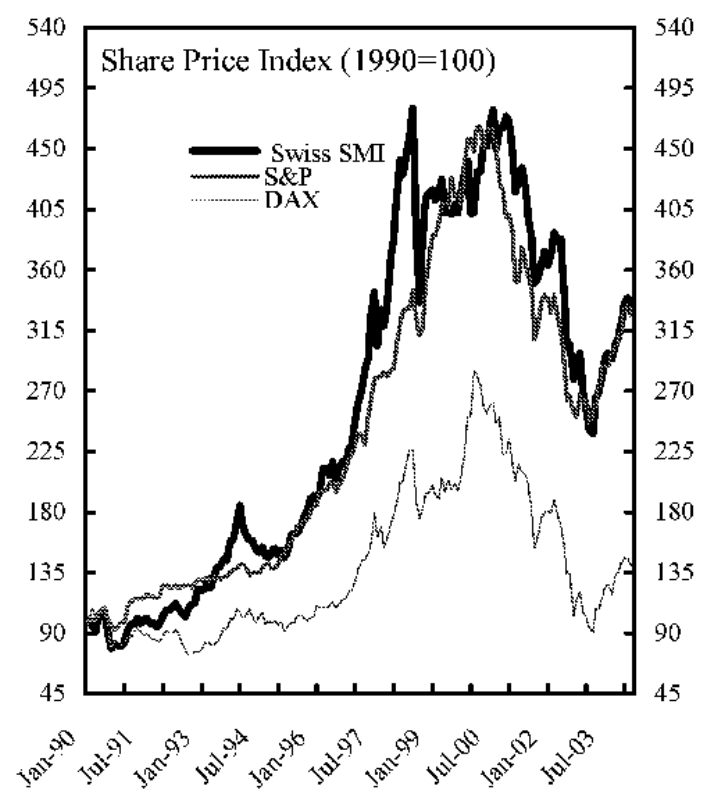

The performance of property prices has been

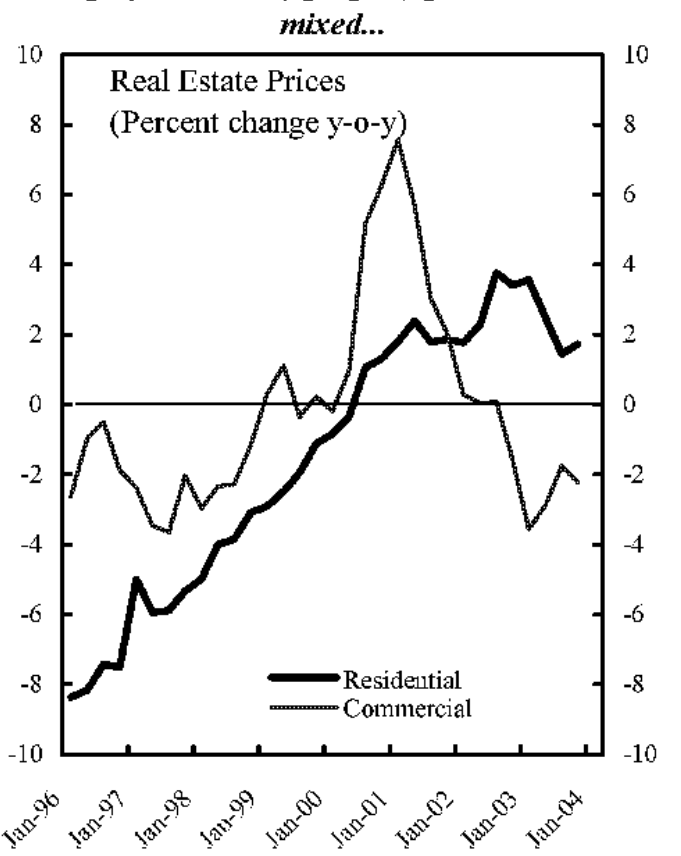

...and despite some declines, the $\mathrm{P} / \mathrm{E}$ ratio remains above its historical average.

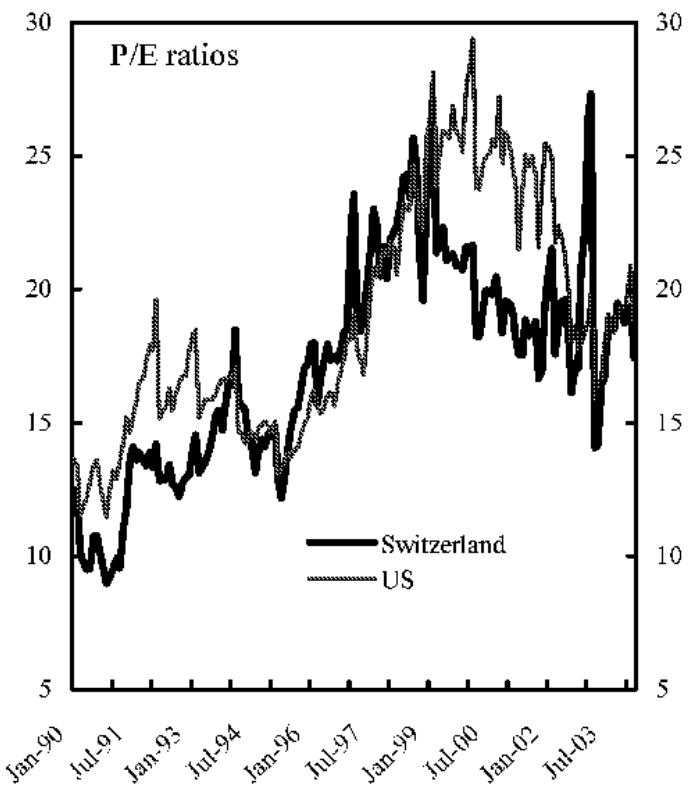

... and current prices are well below their peak in

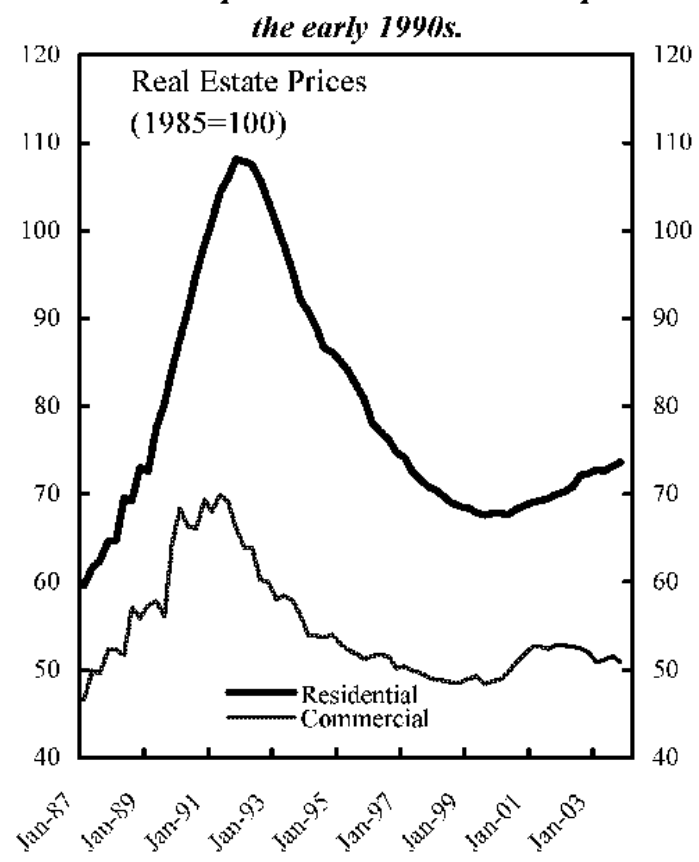

Sources: KOF database; BIS; Bloomberg; and IMF, International Financial Statistics; and IMF staff estimates. 
Figure 7. Switzerland, Short-Term Indicators Suggest a Timid Recovery

The leading economic indicator has strengthened recently...

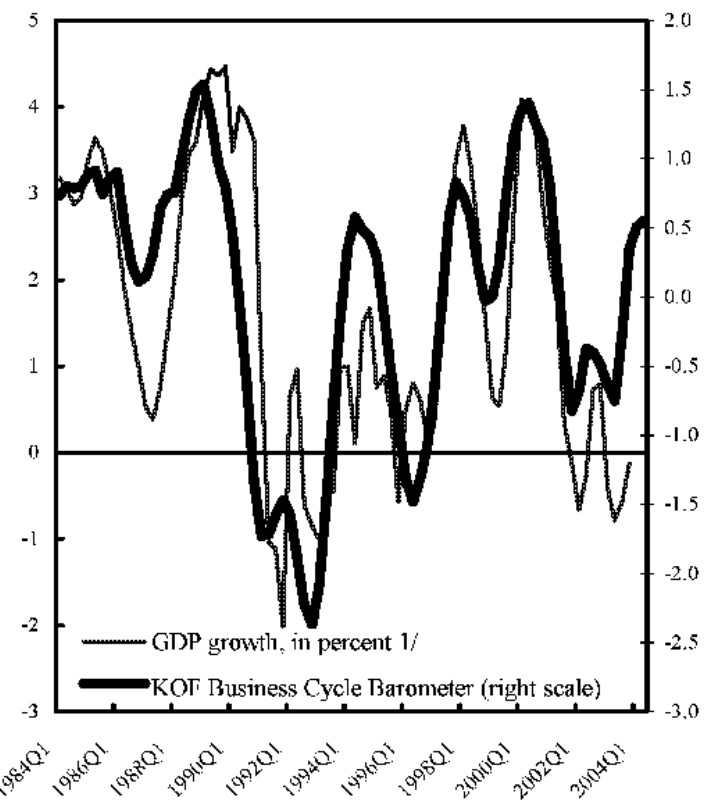

...but less so by the UBS leading indicator...

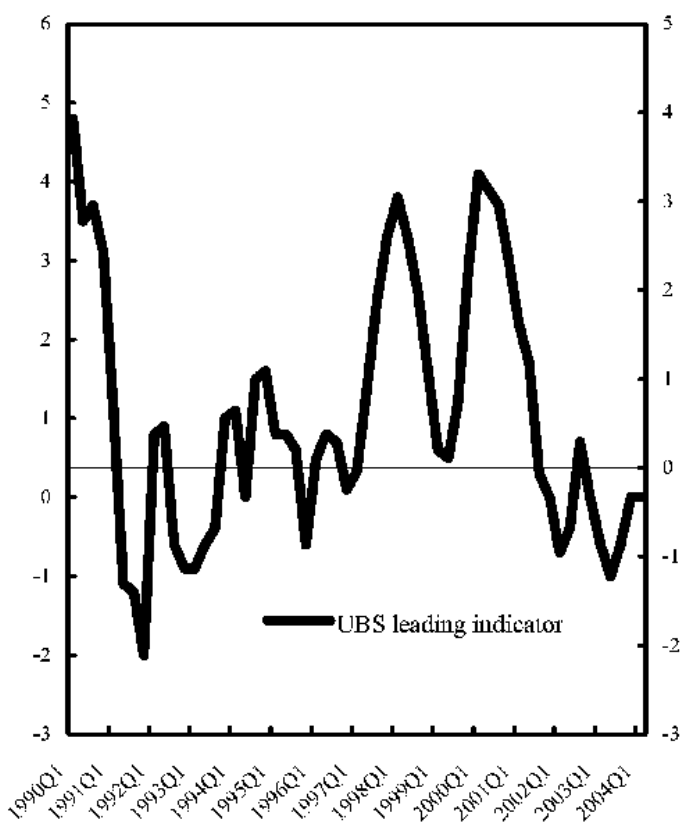

... a trend confirmed by the Purchasing Managers Index...

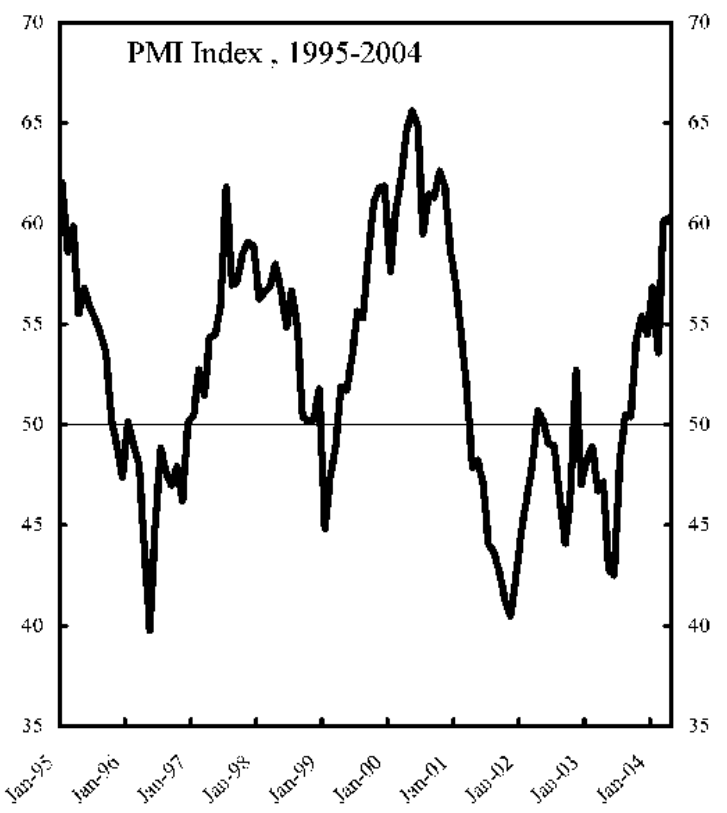

... and consumer confidence surveys.

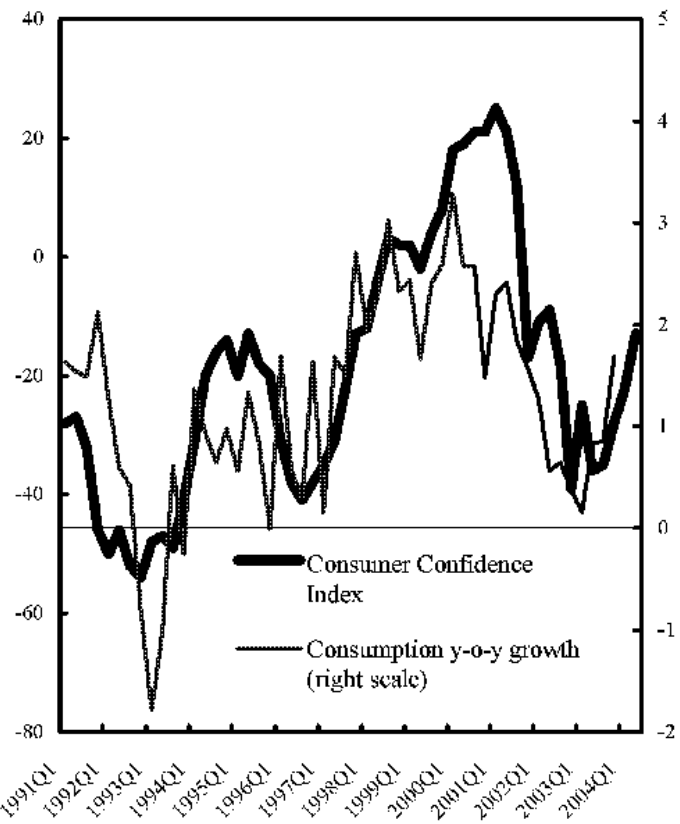

Sources: KOF database; and Bloomberg. 
Figure 8. Switzerland: Money and Credit Aggregates

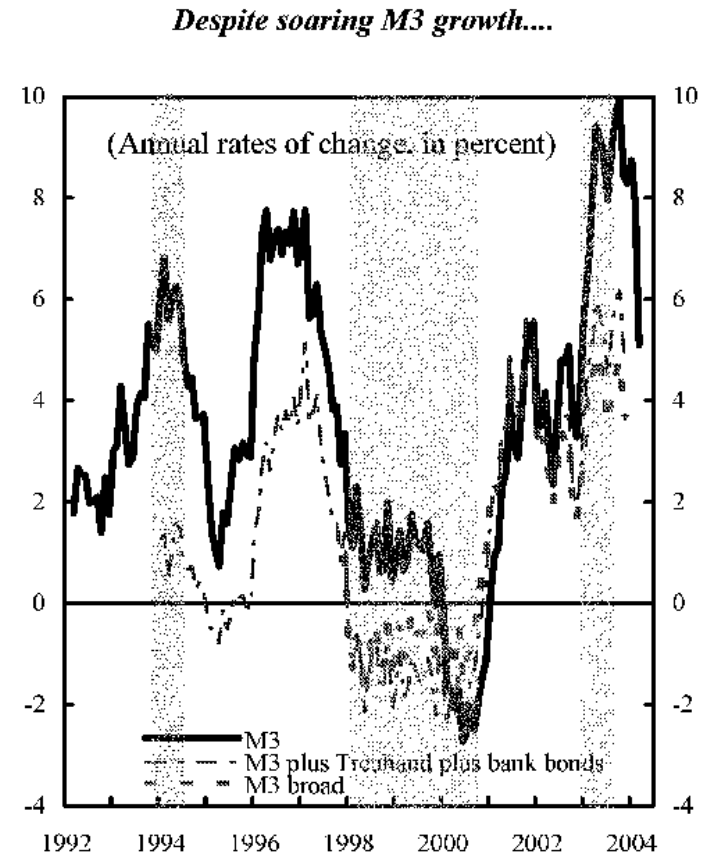

The acceleration of M3 growth correlates with gyrations in stock market prices.
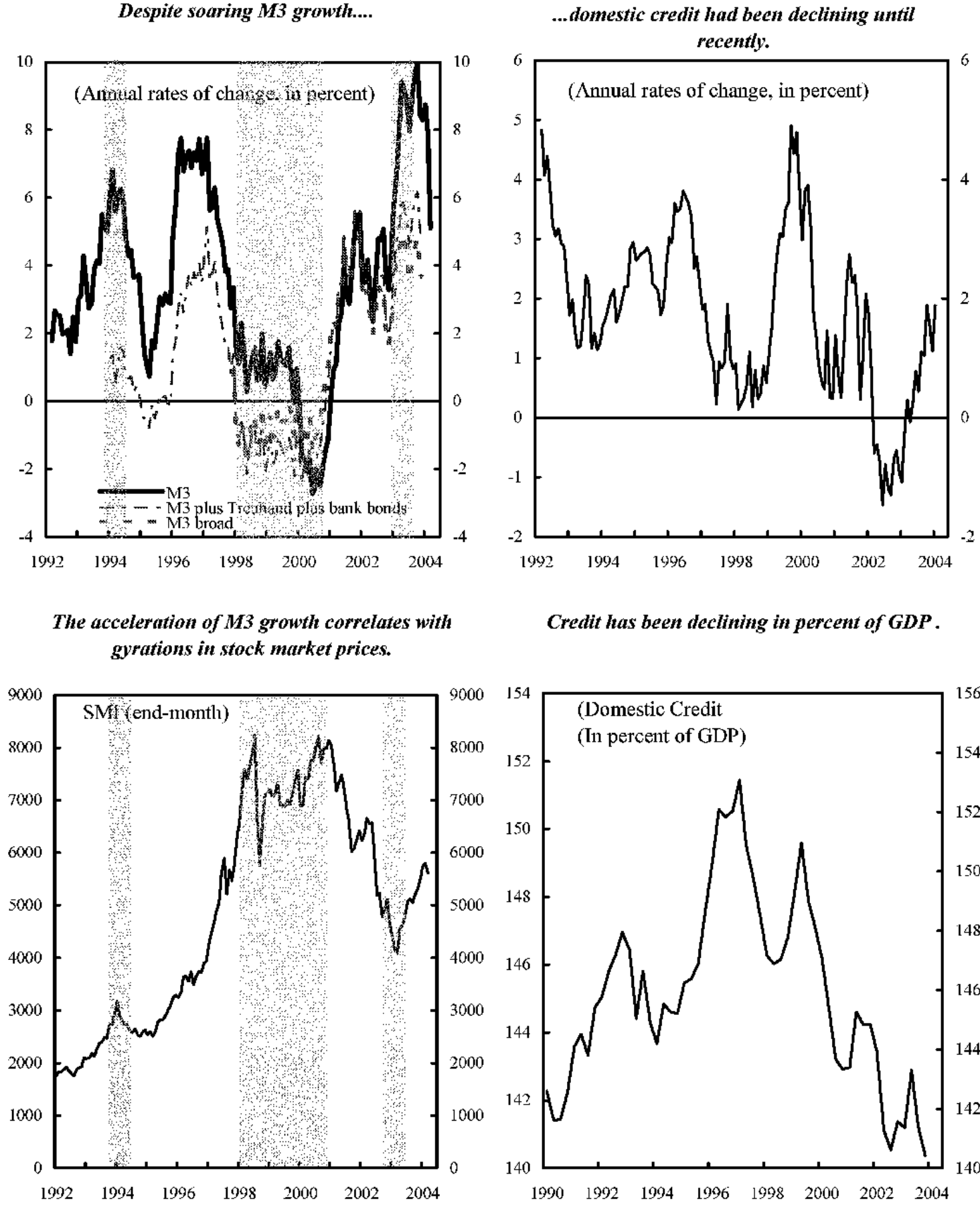

Credit has been declining in percent of GDP.

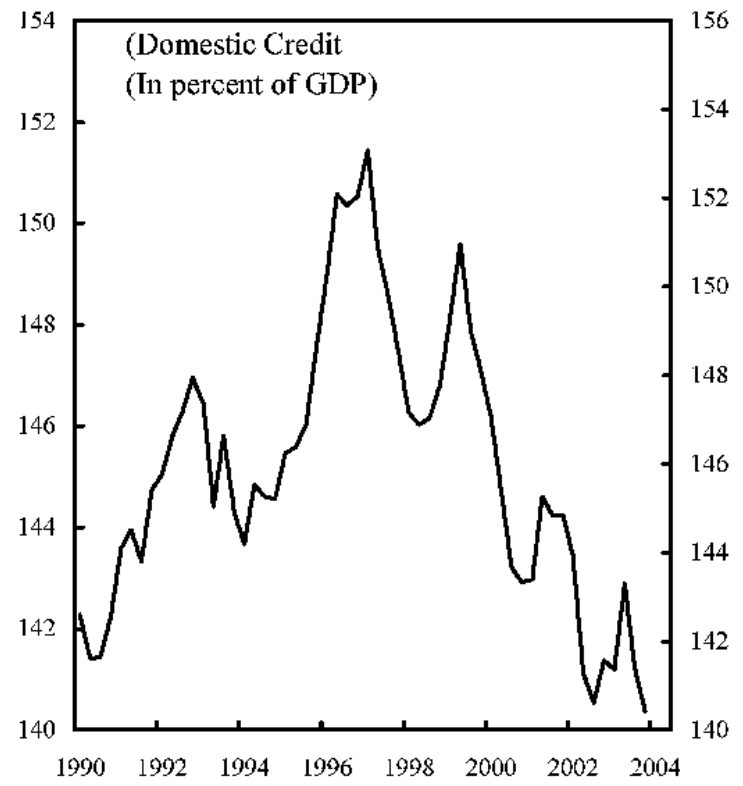

Sources: IMF, World Economic Outlook; and KOF Institute. 
Figure 9. Equity Prices for Bank and Insurance Sectors
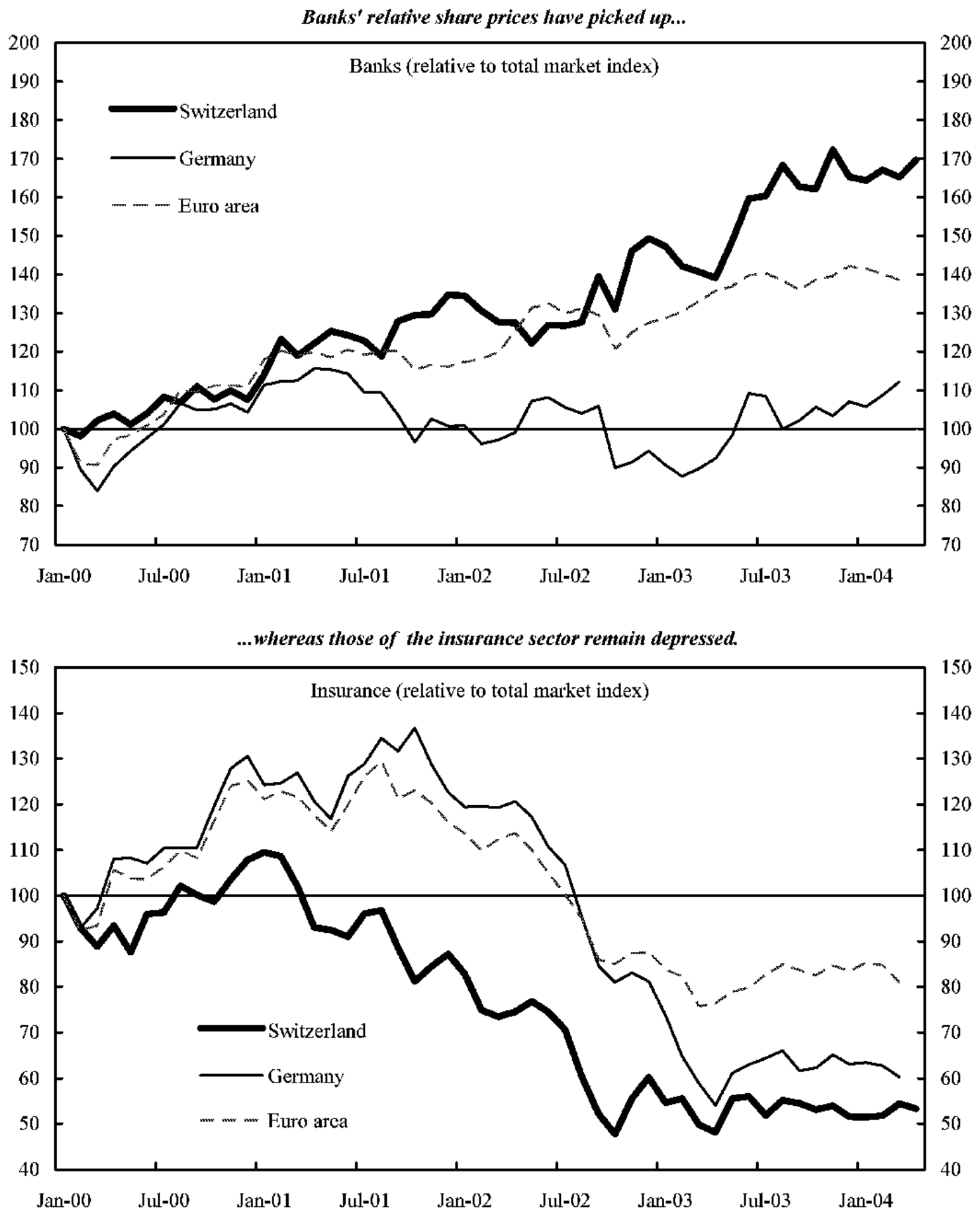

Source: Datastream. 
Figure 10. Switzerland: Structural Indicators

Switzerland is in an enviable position in terms of per capita income...

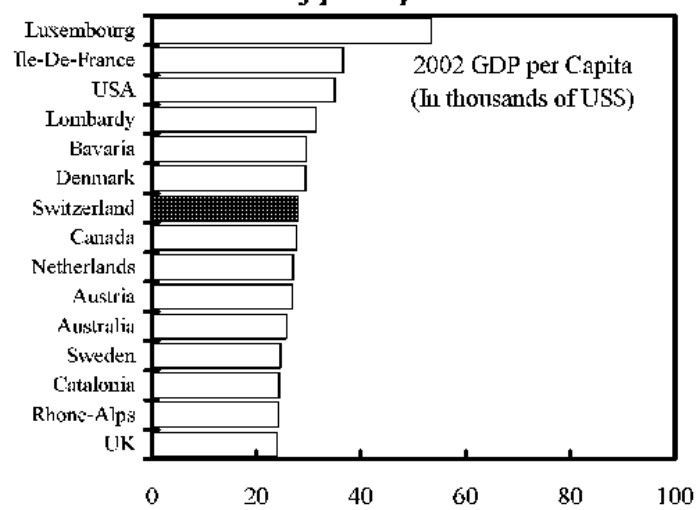

....and quality of life.

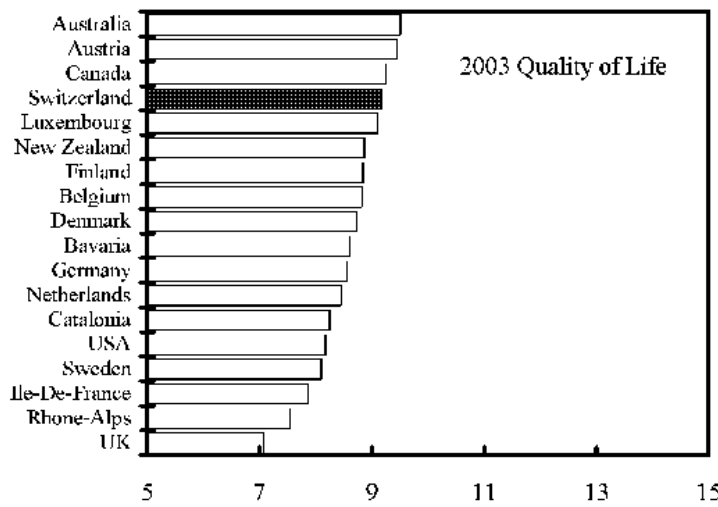

But sluggish product market reform... ${ }^{2 /}$

Despite some erosion in its relative position, Switzerland remains very attractive as a business location. ${ }^{\prime \prime}$

\begin{tabular}{lcc} 
& $\mathbf{2 0 0 0}$ & $\mathbf{2 0 0 3}$ \\
\hline Finland & 3 & 1 \\
Singapour & 2 & 2 \\
Denmark & 10 & 3 \\
Hong Kong & 8 & 4 \\
Switzerland & $\mathbf{4}$ & $\mathbf{5}$ \\
Luxembourg & 6 & 6 \\
Sweden & 7 & 7 \\
Netherlands & 1 & 8 \\
Tceland & 11 & 9 \\
Austria & 12 & 10 \\
\hline
\end{tabular}

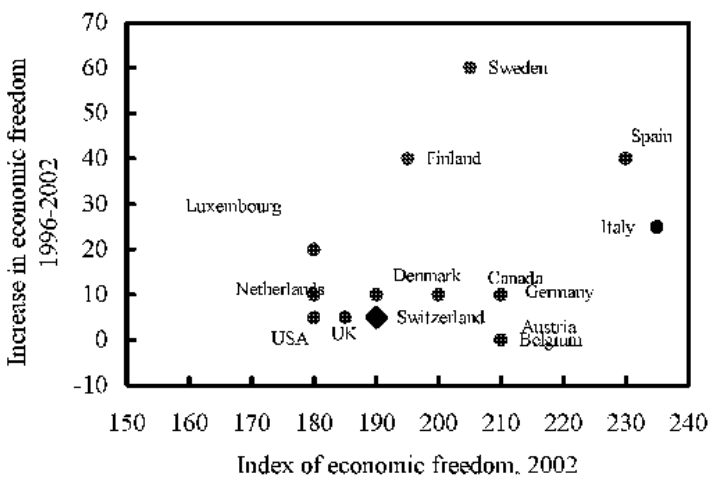

...keeps prices well above EU levels...
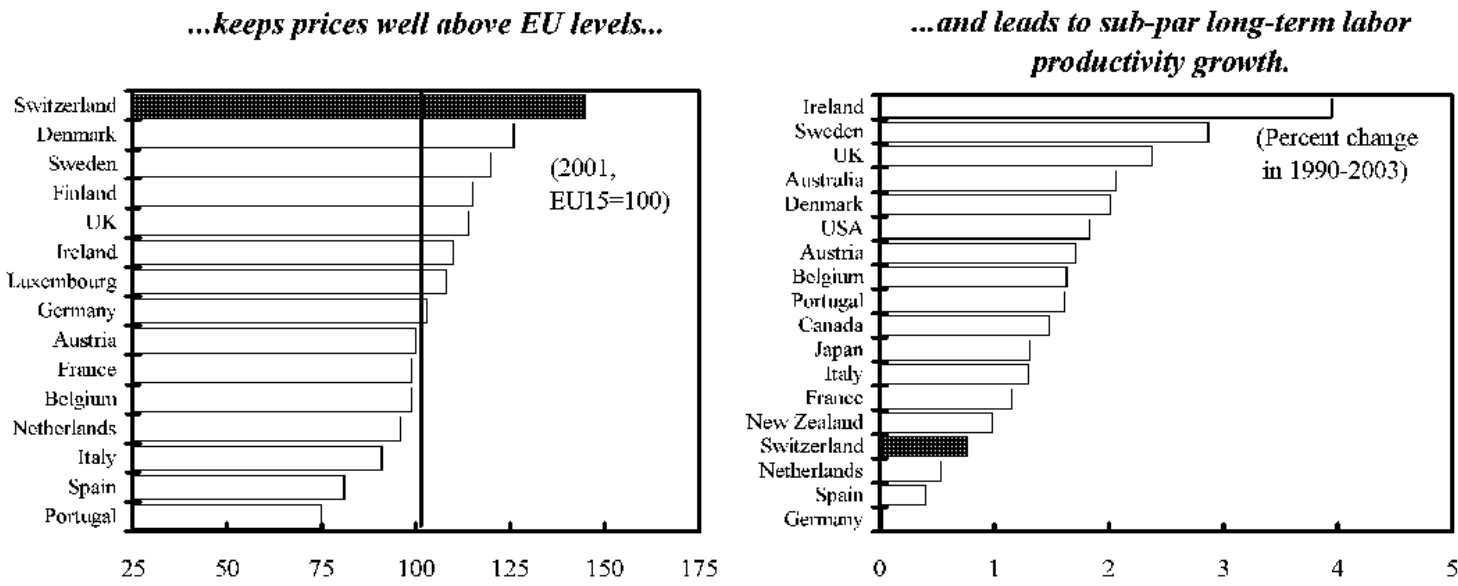

Sources: World Competitiveness Yearbook 2003; Heritage Foundation; Eurostat; and IMF, World Economic Outlook.

1/ Rank of World Competitiveness Index among smaller industrial countries.

2/ The Index of Fconomic Freedom ranges from 100 for free to 500 for repressed environments. 


\section{Switzerland: Fund Relations}

(As of February 29, 2004)

I. Membership Status: Joined 5/29/92; Switzerland has accepted the obligations of Article VIII, Sections 2, 3 and 4.

II. General Resources Account:

Quota

Fund holdings of currency

Reserve position in Fund

III. SDR Department:

Holdings

IV. Outstanding Purchases and Loans:

V. Financial Arrangements: None

VI. Projected Obligations to Fund:

VII. Exchange Rate Arrangement:

\section{SDR Million $\quad \%$ Quota}

$3,458.50$

100.00

$2,092.34$

60.50

$1,366.17$

39.50

SDR Million \% Allocation

84.70

N/A

None

None

The Swiss National Bank does not maintain margins in respect of exchange transactions. However, the Swiss National Bank has intervened when warranted by the circumstances. Switzerland's exchange system is free of restrictions on the making of payments and transfers for current international transactions. However, in accordance with UN resolutions, Switzerland applies exchange restrictions vis-à-vis the Taliban; individuals, groups, and organizations associated with terrorism; and on specific assets of certain persons related to the former regimes in Iraq and the Federal Republic of Yugoslavia and certain persons related to important government functions in Myanmar and Zimbabwe.

\section{Article IV Consultations:}

Switzerland is on the standard 12-month Article IV consultation cycle.

IX. Technical Assistance: None

X. Resident Representatives: None

XI. Other

FSAP, October 2001 


\section{Switzerland: Statistical Issues}

Switzerland publishes timely economic statistics and posts most of the data and the underlying documentation on the internet. Switzerland is in full compliance with the Fund's Special Data Dissemination Standard (SDDS) and its metadata are currently posted on the Dissemination Standards Bulletin Board. However, a number of statistical gaps and deficiencies remain to be addressed: wage statistics are available only on an annual basis; reliable general government finance statistics appear with considerable lags, mainly due to delays in compiling fiscal accounts at the level of cantons and communes; internationally comparable fiscal statistics on an accrual basis are not available; statistics on pension schemes are compiled infrequently and with a long lag; the quarterly national accounts (compiled by the State Secretariat for Economic Affairs) lack a production account; GDP by industry appears with considerable lag; capital stock data and flow-of-funds statistics are not available. To a large extent, these deficiencies reflect a lack of resources and the limited authority of the Federal Statistical Office (BfS) to request information.

To address statistical deficiencies, the authorities have recently taken or intend to take the following steps:

The Swiss National Bank (SNB) has shortened from nine to six months the lag of publishing annual data on the international investment position and, in 2003, started releasing quarterly foreign debt statistics. In 2003, the SNB started also publishing information on bank credit by branch of economic activity, firm size and bank group. And in 2004, the SNB plans to launch a pilot survey on the cost of borrowing.

National accounts were upgraded in 2003 to the European System of Accounts 1995 (ESA95). In this context, the BfS released annual figures for 1990-2002 and the Secretariat for Economics (seco) revised accordingly its quarterly estimates. The main innovations in the new estimates were in investment (which now provides detail on ICT), private and public consumption (where hospitals were transferred to the private sector), and the use of chain price indices (but without adjustment for quality). Moreover, BfS has been working (jointly with the SNB) on the methodology for compiling financial accounts and capital stock data (both for physical and financial capital) and has been negotiating a cooperation agreement with the European Union (EU) for harmonizing Swiss statistics with EU standards.

The Federal Finance Administration has started preparations for the adoption of the Government Finance Statistics Manual 2001 classification and the revamping of the accounting framework, although implementation of the new framework is not expected before 2006. In the interim period, government finance statistics for publication in the GFS Yearbook will be reported on a cash basis but presented in the GFSM 2001 framework. 
Switzerland: Core Statistical Indicators as of April 30, 2004

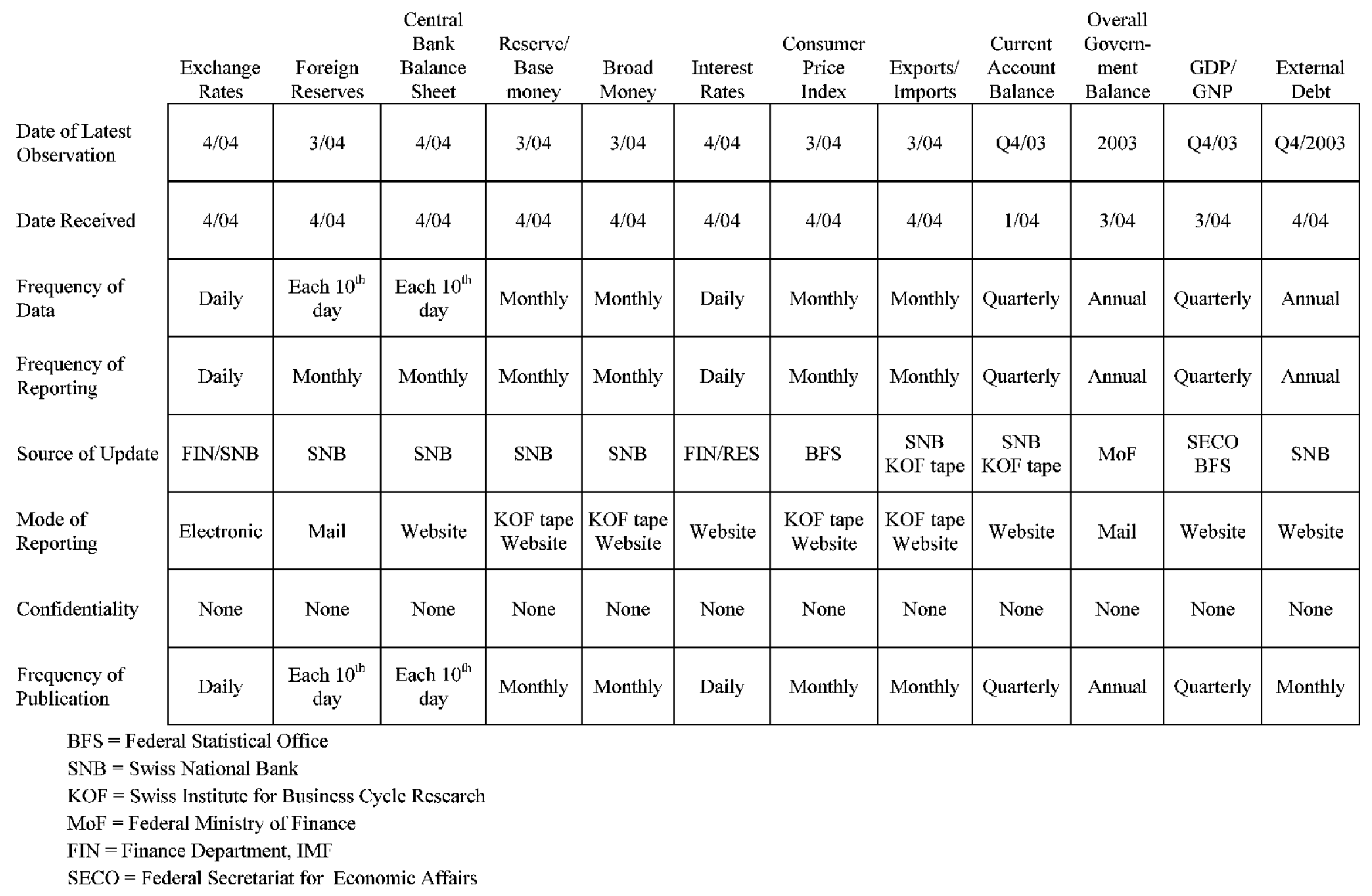




\section{Switzerland: Medium-Term Debt Sustainability Analysis}

Public sector debt sustainability is not a concern for Switzerland. At 56 percent of GDP in 2003, public sector debt is moderate by international standards and is rated AAA by Moodys. Moreover, with net foreign assets at 155 percent of GDP, external debt sustainability is not an issue. Under the baseline scenario, which makes allowance for the recapitalization of former public sector pension funds but abstracts from prospective measures (i.e. Consolidation Plan 2004) and proceeds from the sale of SNB's excess gold reserves and privatization revenue, the debt ratio to hover around 55 percent of GDP (see attached table). The scenario assumes that the current negative output gap is closed in 2008 (which implies that GDP growth exceeds potential growth for a number of years) and interest rates evolve in line with the yield curve.

Setting GDP growth and interest rates at their historic averages and allowing for the recapitalization of former public sector pension plans (scenario A1) gives rise to a small rise in the debt ratio fro 56 to 59 percent of GDP. However, a deep recession (baseline growth minus two standard deviations in 2004 and 2005-scenario B2) could raise the debt ratio by 13 percentage points to 69 percent by 2008 if expenditure plans are not scaled back. This low probability scenario is reminiscent of the Swiss experience in the $1990 \mathrm{~s}$, when very low growth and high unemployment led to a 20 percentage points increase in the debt ratio. The expectation is that the debt-brake rule, which came into effect in 2003 , would force the authorities to take corrective measures at an early stage.

Over the longer run, age-related expenditure are projected to rise considerably as the old-age dependency ratio rises steeply after 2015 and reaches a peak around 2030 (see Selected Issues Paper, IMF Country Report No. 01/75). IMF staff expect that, on unchanged policies, high pension and health care expenditures and lower contributions from a shrinking labor force will put considerable pressure on the federal budget. These problems require reforms in the social welfare system through a combination of cost cutting measures and benefit reductions, rather than increases in contribution rates that would undermine Switzerland's attractiveness as a business location. 


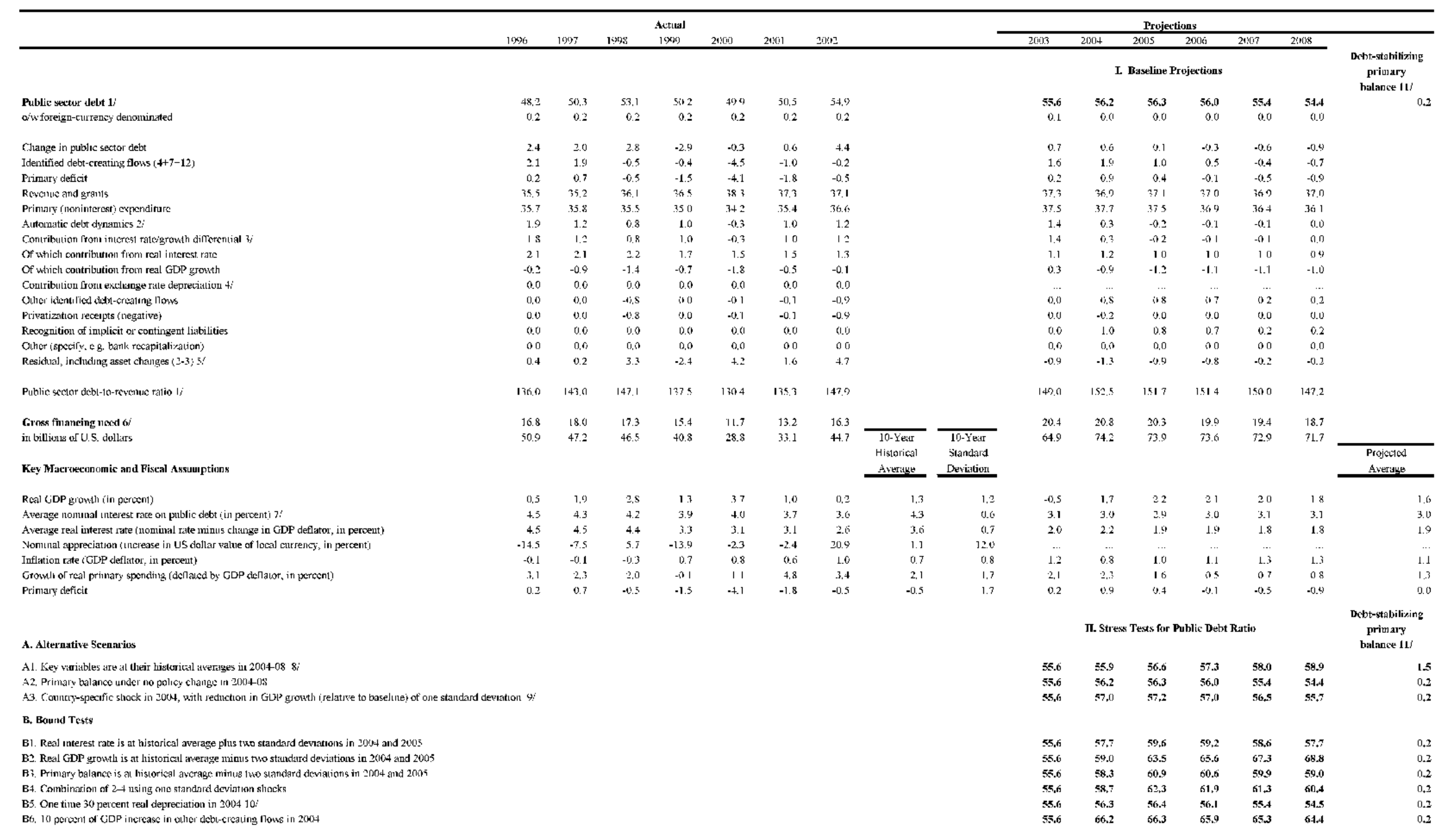

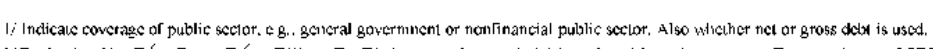

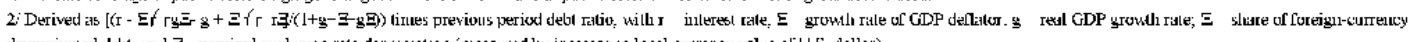

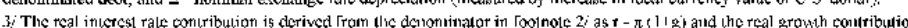

4: The exchange rate contriluntion is derived from the munerator in foomote 2 is $\Xi$ (1-r)

5: For projections. this line inchldes exclangye rate chinuges.

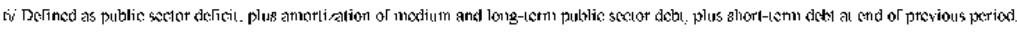

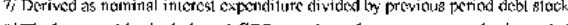

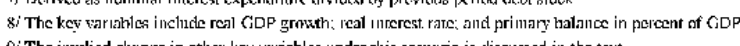

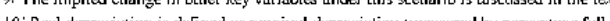

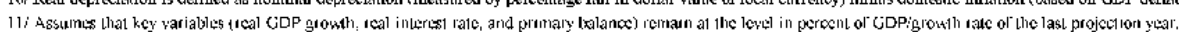




\section{INTERNATIONAL MONETARY FUND}

\section{Public Information Notice}

EXTERNAL

RELATIONS

DEPARTMENT

Public Information Notice (PIN) No. 04/64

International Monetary Fund

FOR IMMEDIATE RELEASE

$70019^{\text {th }}$ Street, NW

June 18, 2004

Washington, D. C. 20431 USA

\section{IMF Concludes 2004 Article IV Consultation with Switzerland}

On June 2, 2004, the Executive Board of the International Monetary Fund (IMF) concluded the Article IV consultation with Switzerland. ${ }^{1}$

\section{Background}

After the Swiss economy flirted with recession for two out of the past three years, there are signs that it has started to grow again on the back of stronger exports and domestic investment and supported by accommodative monetary and fiscal policies. Unemployment has risen, but at 4 percent is low by international standards. Inflation remains negligible and the current account is running a large surplus.

With inflation very low and economic activity weak, the Swiss National Bank (SNB) has relaxed monetary conditions considerably, keeping short-term interest rates close to zero and allowing a rapid expansion of monetary aggregates. The partial reversal of the earlier sharp appreciation of the Swiss franc has reinforced the monetary stimulus. Fiscal policy has been supportive of the recovery, with a projected rise in the general government deficit to 2.5 percent of GDP in 2004, largely reflecting the operation of automatic stabilizers. Assuming that the recovery in Switzerland's main trading partners strengthens, IMF staff projects growth to gather momentum and rise to just over 2 percent in 2005. Inflation is expected to remain very low.

\footnotetext{
' Under Article IV of the IMF's Articles of Agreement, the IMF holds bilateral discussions with members, usually every year. A staff team visits the country, collects economic and financial information, and discusses with officials the country's economic developments and policies. On return to headquarters, the staff prepares a report, which forms the basis for discussion by the Executive Board. At the conclusion of the discussion, the Managing Director, as Chairman of the Board, summarizes the views of Executive Directors, and this summary is transmitted to the country's authorities.
} 


\section{Executive Board Assessment}

Executive Directors commended the authorities' sound macroeconomic policies that have placed the Swiss economy in a good position to benefit from the nascent global recovery. Directors noted, however, that a more ambitious approach to tackle structural rigidities would strengthen competitiveness and longer-term growth performance.

Directors welcomed indications that real GDP growth was rebounding. With inflation expected to remain subdued and activity below potential, they supported the Swiss National Bank's decision to maintain low interest rates and encouraged it to keep the current accommodative monetary policy stance until the recovery is fully secured. Some Directors suggested that the authorities should take appropriate expansionary monetary policies in the near term should deflationary pressures emerge.

Directors noted that the current level of interest rates cannot be maintained indefinitely and, with liquidity building up rapidly, the monetary policy stance would need to be monitored closely and modified proactively. In this respect, they commended the SNB's clear communication strategy and welcomed its new policy of updating the inflation forecast at regular intervals. Directors observed that the monetary policy framework, with its focus on medium-term price stability, has allowed the SNB to respond flexibly to the changing economic environment.

Directors approved of the accommodative fiscal policy and welcomed the commitment to restoring balance in the federal government's accounts. They noted that the transparent and realistic time-table for phasing out the unanticipated structural deficit is appropriate from the current cyclical perspective and preserves the credibility of the debt-brake rule, which requires balance in the federal accounts, after adjustment for the business cycle. Some Directors, however, saw scope for strengthening the rule to counter pressures for sustained fiscal deficits. Directors considered that the additional measures, beyond the 2004 consolidation plan, that are likely to be needed to balance the fiscal position, should focus primarily on cuts in current expenditure, rather than tax increases. They also emphasized the need for enhancing coordination between the federal government and cantonal and communal governments to ensure medium-term fiscal consolidation.

In this connection, Directors underscored the importance of addressing aging-related pressures, and encouraged the authorities to consider new initiatives for old-age and disability pension reform following the rejection of the current reform proposals in the recent referendum. Directors considered that although Switzerland, with its greater reliance on the fully-funded second pillar of its pension system, was better prepared than most other industrial countries to face aging-related challenges, it needed to act at an early stage to ameliorate the burden on future generations.

Directors commended the authorities for acting promptly to ease the strains on second pillar pension funds but underscored the need for further action in strengthening prudential supervision and eliminating regulatory arbitrage. Directors considered the reduction of the minimum guaranteed interest rate on pensioners' assets as a necessary first step and 
encouraged the authorities to put in place a predictable, rule-based mechanism in setting the minimum interest rate.

Directors noted the resilience of the Swiss financial system in the face of recent shocks. They commended the authorities' sound supervisory framework and their continued efforts to strengthen it further, particularly in the area of insurance. In this context, Directors welcomed steps to create an integrated financial market supervisory authority, revamp the insurance regulatory framework, strengthen external auditing, and improve corporate governance. Directors endorsed the efforts to strengthen further the framework for anti-money laundering and combating terrorist financing (AML/CFT) and commended the authorities' commitment to ensure that the AML/CFT framework meets high international standards.

Directors supported the renewed emphasis on long-overdue structural reforms, noting that slow progress so far in addressing structural rigidities in the highly protected domestic product markets has contributed to more than a decade of poor growth performance. In this regard, Directors welcomed the strengthening of the Competition Authority and underscored the need for decisive steps to reduce barriers in the internal market, cut red-tape, and create a leaner and uniform regulatory environment for products, services, and network industries across Switzerland, overcoming the excess regulation at lower levels of government.

Directors welcomed the conclusion of negotiations with the EU for a package of bilateral treaties that has also allowed agreement on the taxation of income from savings. Directors commended the authorities' initiative to eliminate all trade barriers to imports from poor countries.

They encouraged them to accelerate the dismantling of the high level of trade protection and subsidization of agriculture. They commended the authorities for the effectiveness of Swiss official development assistance (ODA) and welcomed the intention to raise ODA to 0.4 percent of GNP by 2010 . Some Directors encouraged the authorities to move closer to the United Nations target.

Directors noted that Switzerland's economic statistics are generally adequate for surveillance purposes and welcomed continuing improvements, including the introduction of the European System of Accounts. Directors noted, however, that, in certain areas, data deficiencies hampered the quality of economic analysis and policy advice and urged the authorities to take corrective action.

Public Information Notices (PINs) Public Information Notices (PINs) form part of the IMF's efforts to promote transparency of the IMF's views and analysis of economic developments and policies. With the consent of the country (or countries) concerned, PINs are issued after Executive Board discussions of Article IV consultations with member countries, of its surveillance of developments at the regional level, of post-program monitoring, and of ex post assessments of member countries with longer-term program engagements. PINs are also issued after Executive Board discussions of general policy matters, unless otherwise decided by the Executive Board in a particular case. 
Switzerland: Selected Economic Indicators

\begin{tabular}{|c|c|c|c|c|c|c|}
\hline & 1999 & 2000 & 2001 & 2002 & 2003 & $20041 /$ \\
\hline \multicolumn{7}{|l|}{ Real economy } \\
\hline Real GDP & 1.3 & 3.7 & 1.0 & 0.2 & -0.5 & 1.7 \\
\hline Real total domestic demand & 0.3 & 2.2 & 1.9 & -0.9 & 0.1 & 2.2 \\
\hline CPI (year average) & 0.8 & 1.6 & 1.0 & 0.6 & 0.6 & 0.3 \\
\hline Unemployment rate ( $\mathrm{n}$ percent of labor force) & 2.7 & 1.8 & 1.7 & 2.5 & 3.7 & 3.4 \\
\hline Gross national saving (percent of GDP) & 30.5 & 32.5 & 27.6 & 27.3 & 28.3 & 28.8 \\
\hline Gross national investment (percent of GDP) & 19.0 & 20.0 & 19.1 & 18.8 & 18.0 & 19.2 \\
\hline \multicolumn{7}{|l|}{ Public finances (percent of GDP) } \\
\hline Confederation budget balance $2 /$ & -0.8 & 0.9 & -0.4 & -0.1 & -0.9 & -1.3 \\
\hline General government balance $2 / 3 /$ & -0.6 & 2.2 & 0.0 & -1.2 & -1.9 & -2.5 \\
\hline Gross public debt & 50.2 & 49.9 & 50.5 & 54.9 & 55.6 & 56.2 \\
\hline \multicolumn{7}{|l|}{ Balance of payments } \\
\hline Trade balance (in percent of GDP) & -0.1 & -1.0 & -1.1 & 1.2 & 1.1 & 0.7 \\
\hline Current account (in percent of GDP) & 11.5 & 12.5 & 8.5 & 8.5 & 10.2 & 9.6 \\
\hline Official reserves (end of year, US\$ billion) $4 / 7 /$ & 36.3 & 32.3 & 32.0 & 40.2 & 47.6 & 49.8 \\
\hline \multicolumn{7}{|l|}{ Money and interest rates } \\
\hline Domestic credit (end of year) $5 /$ & 3.8 & 0.3 & 2.1 & -0.9 & 1.1 & 1.9 \\
\hline M3 (end of year) $7 /$ & 0.9 & -1.2 & 5.5 & 4.2 & 8.3 & 7.9 \\
\hline Three-month Libor rate (in percent) 6 I & 1.4 & 3.1 & 2.9 & 1.2 & 0.3 & 0.3 \\
\hline Government bond yield (in percent) $6 /$ & 2.9 & 3.8 & 3.3 & 3.1 & 2.5 & 2.5 \\
\hline \multicolumn{7}{|l|}{ Exchange rate } \\
\hline Exchange rate regime & \multicolumn{6}{|c|}{ Managed float } \\
\hline Present rate (April 13, 2004) & \multicolumn{6}{|c|}{ SwF 1.30 per US\$1 } \\
\hline Nominal effective exchange rate $(1990=100) 7 /$ & 106.0 & 105.1 & 109.2 & 113.6 & 113.2 & 110.7 \\
\hline Real effective exchange rate $\langle 1990=100) 7 / 8 /$ & 100.2 & 97.8 & 100.7 & 104.4 & 104.0 & 102.0 \\
\hline
\end{tabular}

Sources: IMF, International Financial Statistics; IMF, World Economic Outlook; and IMF staff projections.

$1 /$ Staff estimates and projections

$2 /$ Including privatization revenue.

$3 /$ Including Confederation, cantons, communes, and social security.

4/ Excluding gold.

5/ Figures for 2004 refer to a change from January 2003 to January 2004.

6/ Figures for 2004 refer to March.

7/ Figures for 2004 refer to February.

$8 /$ Based on consumer prices. 


\section{Statement by Fritz Zurbrügg, Executive Director for Switzerland June 2, 2004}

1. I would like to thank staff on behalf of my Swiss authorities for the as usual very constructive policy discussions and the comprehensive report. The report accurately describes the economic situation in Switzerland and the main policy challenges. My authorities broadly agree with the staff's appraisal and recommendations, and they look forward to the publication of the staff report.

2. The long-awaited and repeatedly delayed economic upswing seems finally underway. Although GDP contracted slightly in 2003 as a whole, economic activity started to pick up in the second half of 2003. Indications that the recovery is gathering steam have strengthened further since the release of the staff report. Real GDP growth in the first quarter of 2004 reached 0.4 percent quarter-on-quarter and 1.5 percent year-on-year. Strong exports were the driving force behind this performance. But the recovery is also broadening. Business investment and private consumption are increasing, and almost all sectors are benefiting from the recovery. Unemployment has started to decline and the index of consumer sentiment is at its highest level in two years. Furthermore, this week the KOF (main independent forecasting institute) economic barometer for Switzerland, which consists of six leading indicators and has a leading horizon of 6-9 months, came in significantly higher than expected, suggesting that growth will continue to accelerate into the second half of 2004.

\section{Monetary Policy}

3. Staff's analysis of monetary conditions and monetary policy coincides with the views of the Swiss National Bank (SNB). Monetary policy is supporting the recovery, but as noted by staff, the current very low level of interest rates cannot be maintained indefinitely. With the signs of a sustainable recovery firming, the need for a policy tightening is increasing. At the current monetary stance, the SNB inflation forecast predicts inflation to exceed 2 percent in two years from now.

4. As staff rightly notes, monetary expansion has been rapid and needs to be monitored closely. Although the short-term relation between monetary growth and inflation is rather tenuous, the long-term relation is quite robust. Monetary aggregates, particularly M3, are volatile mainly due to the exclusion of fiduciary accounts. However, current empirical research undertaken at the SNB does not suggest that money demand is unstable.

5. The SNB's monetary policy aims to maintain price stability, i.e., to prevent both inflation and deflation. My authorities do not believe it possible to fine-tune inflation within the $0-2$ percent price stability range. In a small open economy inflation is subject to external erratic influences and hence hardly controllable within a narrow range. In the view of the SNB, striving to precisely control inflation would most likely cause monetary policy to become itself a source of destabilization. 


\section{Fiscal Policy}

6. Staff notes that the overall fiscal position is relatively sound, but it rightly points out that longer-term challenges remain. In a referendum on May 16, voters rejected a government-proposed increase in VAT, a reduction in federal income taxes, and a series of amendments to the old-age insurance (first pillar). For the budget, these rejections have a negative impact for the short term but a positive impact over the medium term. The rejection of the VAT increase will reduce revenues for the Confederation by SwF 0.3-0.4 billion from 2005 onwards, while the rejection of the income tax cuts will result in higher than projected revenues by about SwF 0.6 billion in 2006 and SwF 1.1 billion from 2007 onwards.

7. Over the longer run, however, the need for further fiscal consolidation persists. Moreover, some of the reforms that have been rejected by voters will have to be readdressed. This is particularly true with regard to safeguarding the financing of the old-age insurance. The rejected reform package envisaged savings on the expenditure side as well as higher funding. As to the rejected income tax reform, tax cuts were aimed at families, shareholders and property owners. Some of these issues will have to be revisited, particularly the stamp duty on securities and the marriage penalty.

8. Staff raises concerns that cuts in federal expenditure have been disproportionately carried out on public investment. However, the evidence provided in para 22 is misleading due to the selected base year. In 1997, a substantial loan from the Confederation to the unemployment insurance, which is accounted for as capital expenditure, inflated investment expenditure. Net of this loan, capital expenditure actually expanded significantly. In addition, the definition of public investments does not adequately account for spending items related to research and education and is thus biased towards physical infrastructure.

9. My authorities agree with staff that the debt-brake has so far proven to be an effective instrument of ensuring fiscal discipline. They took note of staff's suggestions for fine tuning. However, they are not fully convinced that a model-based approach to adjust the cyclical fluctuations of specific revenue components would, overall, represent a major improvement over the current system.

\section{Financial Sector}

10. The Swiss financial sector regulatory and supervisory framework is continuously being improved in line with international standards and practices. The ambitious reform schedule is on track and three major projects were brought to the stage of public consultation: the draft law for an integrated financial market supervisory authority, the draft for a revised and EU-compatible law on collective investment schemes, and revised rules for granting administrative assistance in matters relating to the stock exchange. In the field of pension fund regulation, two expert commissions have brought forward reports on optimizing the supervision and the legal structure of pension funds. Their recommendations include a strengthening of the prudential element in the supervision of second pillar assets, aiming at administrative and financial independence of the authorities in charge, and reviewing the current institutional setup. The bill to expand the catalogue of measures referring to underfunding of pension funds is currently being debated in Parliament. 


\section{Structural Issues}

11. Raising growth potential through structural reforms remains the main policy challenge for Switzerland. On the positive side, Switzerland has a relatively small public sector, very flexible labor markets, a high rate of capital accumulation, and it is very open to external trade. However, as mentioned by staff, inefficiencies in some sheltered domestic markets keep costs high and act as a drag on productivity. My Swiss authorities are working on several of these issues. The revised antitrust law and the new Internal Market Act are expected to increase competition in domestic markets.

12. On May 19, 2004, Switzerland and the EU reached agreement on a new set of bilateral accords in nine areas, including on measures to enhance cooperation against tax evasion. Switzerland will introduce a withholding tax on income from savings of EU residents and transfer 75 percent of the proceeds to the respective EU member state. Other areas of agreement concern Switzerland's participation in the Schengen system, cooperation in the area of statistics, and the liberalization of trade in processed agricultural goods. In addition, Switzerland has agreed to extend the first set of accords, which took effect in June 2002, to the ten countries that joined the EU on May 1, including the free movement of persons. Switzerland has also offered to contribute to the EU cohesion fund.

13. As staff points out, agricultural protection continues to be relatively high. However, my authorities would like to note that the new agricultural policy results in a substantial switch from price support to direct payments. In the 2004-7 budget period, price support and export subsidies will account for only 21 percent of public expenditure on agriculture, compared to 63 percent ten years ago. The direct payment system assures full compatibility with very high ecological and ethological standards. Moreover, total expenditure on agriculture is projected to decline compared to the 2000-3 period.

14. Despite the current pressure on the budget, my Swiss authorities would like to assure the Executive Board that official development aid remains high on the agenda. According to latest OECD statistics, Switzerland's ODA share reached 0.38 percent of GNI in 2003 (new definition). With regard to the dismantling of trade protection as a contribution to helping poor countries, Switzerland recently further reduced preferential tariffs for products originating from LDCs. This represents an important step forward in reaching the stated objective of the Swiss Government to provide duty-free and quota-free access for all LDC products. While most products of interest to LDCs are already duty-free, tariff reductions for the remaining agricultural products amount to $55-75$ percent. 